\title{
Sarcoglycan Alpha Mitigates Neuromuscular Junction Decline in Aged Mice by Stabilizing LRP4
}

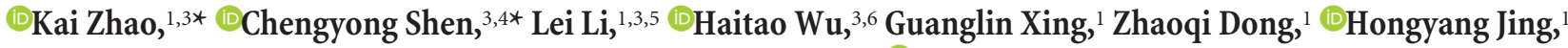 \\ Wenbing Chen, ${ }^{1}$ Hongsheng Zhang, ${ }^{1}$ Zhibing Tan, ${ }^{1}$ Jinxiu Pan, ${ }^{1}{ }^{-}$Lei Xiong, ${ }^{1}$ Hongsheng Wang, ${ }^{1}$ Wanpeng Cui, ${ }^{1}$

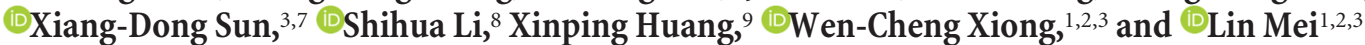 \\ ${ }^{1}$ Department of Neurosciences, School of Medicine, Case Western Reserve University, Cleveland, Ohio 44106, ${ }^{2}$ Louis Stokes Cleveland Veterans Affairs \\ Medical Center, Cleveland, Ohio 44106, ${ }^{3}$ Department of Neuroscience and Regenerative Medicine, Medical College of Georgia, Augusta University, Augusta, \\ Georgia 30912, ${ }^{4}$ Institute of Translational Medicine, First Affiliated Hospital, Zhejiang University, Hangzhou, China 310020, ${ }^{5}$ School of Life Science and \\ Technology, Shanghai Tech University, Shanghai, China 201210, ${ }^{6}$ Department of Neurobiology, Institute of Basic Medical Sciences, Beijing, China 100850, \\ ${ }^{7}$ Department of Neurology, School of Basic Medical Sciences, Second Affiliated Hospital, Guangzhou Medical University, Guangzhou, China 510260, \\ ${ }^{8}$ Department of Human Genetics, School of Medicine, Emory University, Atlanta, Georgia 30322, and ${ }^{9}$ Center for Neurodegenerative Disease, School of \\ Medicine, Emory University, Atlanta, Georgia, 30322
}

During aging, acetylcholine receptor (AChR) clusters become fragmented and denervated at the neuromuscular junction (NMJ). Underpinning molecular mechanisms are not well understood. We showed that LRP4, a receptor for agrin and critical for NMJ formation and maintenance, was reduced at protein level in aged mice, which was associated with decreased MuSK tyrosine phosphorylation, suggesting compromised agrin-LRP4-MuSK signaling in aged muscles. Transgenic expression of LRP4 in muscles alleviated AChR fragmentation and denervation and improved neuromuscular transmission in aged mice. LRP4 ubiquitination was augmented in aged muscles, suggesting increased LRP4 degradation as a mechanism for reduced LRP4. We found that sarcoglycan $\alpha$ (SG $\alpha$ ) interacted with LRP4 and delayed LRP4 degradation in cotransfected cells. AAV9-mediated expression of $\mathrm{SG} \alpha$ in muscles mitigated AChR fragmentation and denervation and improved neuromuscular transmission in aged mice. These observations support a model where compromised agrinLRP4-MuSK signaling serves as a pathological mechanism of age-related NMJ decline and identify a novel function of SG $\alpha$ in stabilizing LRP4 for NMJ stability in aged mice.

Key words: aging; LRP4; neuromuscular junction; $\mathrm{SG} \alpha$

Significance Statement

This study provides evidence that LRP4, a receptor of agrin that is critical for NMJ formation and maintenance, is reduced at protein level in aged muscles. Transgenic expression of LRP4 in muscles ameliorates AChR fragmentation and denervation and improves neuromuscular transmission in aged mice, demonstrating a critical role of the agrin-LRP4-MuSK signaling. Our study also reveals a novel function of SG $\alpha$ to prevent LRP4 degradation in aged muscles. Finally, we show that NMJ decline in aged mice can be mitigated by AAV9-mediated expression of $\mathrm{SG} \alpha$ in muscles. These observations provide insight into pathological mechanisms of age-related NMJ decline and suggest that improved agrin-LRP4-MuSK signaling may be a target for potential therapeutic intervention.

\section{Introduction}

Motor neurons in the spinal cord innervate muscle fibers to form the neuromuscular junctions (NMJs; Sanes and Lichtman, 2001;
Wu et al., 2010a; Li et al., 2018). This peripheral synapse is critical for muscle contraction. In addition, motor neurons are thought to have trophic effect on muscle wellbeing because denervated

\footnotetext{
Received April 3, 2018; revised Aug. 7, 2018; accepted Aug. 22, 2018.

Author contributions: K.Z. wrote the first draft of the paper; K.Z. edited the paper; K.Z.,W.-C.X., and L.M. designed research; K.Z., C.S., L.L., H.W., G.X., Z.D., H.J., W.-B.C., H.Z., Z.T., J.P., L.X., H.-S.W., W.C., and X.-D.S. performed research; H.W., S.L., X.H., W.-C.X., and L.M. contributed unpublished reagents/analytic tools; K.Z., C.S., L.L., H.W., G.X., Z.-Q.D., H.J., W.-B.C., H.Z., Z.T., J.-X.P., L.X., H.-S.W., W.C., and X.-D.S. analyzed data; K.Z., C.S., Z.-Q.D., and L.M. wrote the paper.

This work was supported by Grants from the National Institute on Aging (AG051510), Veterans Affairs, and the Viral Vector core at Emory University Department of Neurology (NINDS Core Facilities Grant P30NS055077).
}

The authors declare no competing financial interests.

*K.Z. and C.S. contributed equally to this work.

Correspondence should be addressed to either of the following: Dr. Lin Mei, Department of Neurosciences, School of Medicine, Case Western Reserve University, 10900 Euclid Avenue, Cleveland, OH 44106-4975, E-mail: lin.mei@case.edu; or Chengyong Shen, 268 Kaixuan Road, Institute of Translational Medicine, First Affiliated Hospital, Zhejiang University, Hangzhou, China, E-mail: cshen@zju.edu.cn. DOI:10.1523/JNEUROSCI.0860-18.2018

Copyright $\odot 2018$ the authors $\quad 0270-6474 / 18 / 388860-14 \$ 15.00 / 0$ 
muscle fibers become atrophic (Pellegrino and Franzini, 1963; Stonnington and Engel, 1973; Hamburger, 1980; Delbono, 2003). Evidence suggests that muscle aging is associated with NMJ decline (Gutmann et al., 1971; Courtney and Steinbach, 1981; Grimby and Saltin, 1983; Doherty et al., 1993; Roos et al., 1997; Deschenes et al., 2010; Valdez et al., 2010; Samuel et al., 2012). Typically, acetylcholine receptor (AChR) clusters on the postjunctional membrane are fragmented into small islands in aged mice and AChR density is reduced; the perimeter lengths of AChR-stained areas are increased (Deschenes et al., 2010; Valdez et al., 2010; Li et al., 2011). Motor axon terminals are disorganized and contain varicosities (Rosenheimer, 1990; Kawabuchi et al., 2001; Messi and Delbono, 2003; Valdez et al., 2010; Chai et al., 2011; Wang et al., 2011). Some clusters are not or only partially innervated or innervated by multiple axon terminals (Gutmann and Hanzlíková, 1966; Courtney and Steinbach, 1981; BaliceGordon, 1997; Valdez et al., 2010; Chai et al., 2011; Samuel et al., 2012). There appears to be a reduction in the number of motor neurons and in the number and diameter of axons in the ventral roots (Tomlinson and Irving, 1977; Mittal and Logmani, 1987; Hashizume et al., 1988; Valdez et al., 2010). Perhaps due to motor neuron loss and reinnervation of muscle fibers that have lost innervation by neighboring axons, the number of motor units is reduced (Larsson and Ansved, 1995; Delbono, 2003) and neurotransmission in remaining NMJs was reduced or altered (Gutmann et al., 1971; Banker et al., 1983; Kelly and Robbins, 1983; Kurokawa et al., 1999).

The NMJ formation is controlled by the agrin-LRP4-MuSK pathway. During embryonic development, motor neuron terminals release agrin that binds to LRP4, a transmembrane protein, to activate the transmembrane tyrosine kinase MuSK (DeChiara et al., 1996; Gautam et al., 1996; Glass et al., 1996; Weatherbee et al., 2006; Kim et al., 2008; Zhang et al., 2008); and ensuing intracellular signaling that leads to NMJ formation. Recent studies indicate that this pathway is critical for NMJ maintenance. Conditional mutation of agrin, LRP4 or MuSK after NMJ formation causes NMJ disintegration (Hesser et al., 2006; Samuel et al., 2012; Barik et al., 2014). There are antibodies against agrin, LRP4, and MuSK in patients with myasthenia gravis, an acquired autoimmune disorder (Hoch et al., 2001; Pevzner et al., 2012; Zhang et al., 2012, 2014; Gasperi et al., 2014). In animal models, inducing antibodies against agrin, LRP4 or MuSK causes muscle weakness, impairs neuromuscular transmission and disrupts NMJ structure (Jha et al., 2006; Klooster et al., 2012; Huijbers et al., 2013; Shen et al., 2013; Yan et al., 2018).

In this study, we showed that LRP4 was reduced at protein level in muscles of aged mice, accompanied by weakened MuSK tyrosinephosphorylation, an indicator of kinase activation. Expression of LRP4 specifically in muscles ameliorated aging-associated deficits including AChR cluster fragmentation, denervation, and impaired neuromuscular transmission. To understand the mechanisms of LRP4 reduction in aged muscles, we screened for proteins that were implicated in NMJ and muscle stability, which were also reduced in aged muscles. This led to the identification of sarcoglycan $\alpha(\mathrm{SG} \alpha)$, a key component of the dystrophinglycoprotein complex (DGC). We found that SG $\alpha$ was present at the NMJ, and $\mathrm{SG} \alpha$, but not SG $\delta$, interacted with LRP4. Enhancing SG $\alpha$ level increased the stability of LRP4. Viral expression of SG $\alpha$ diminished aging-associated NMJ deficits in vivo. Together, the results reveal LRP4 reduction as a mechanism of NMJ decline in aged mice and identify agrin-LRP4-MuSK signaling as unappreciated therapeutic target.

\section{Materials and Methods}

Mouse lines generation and genotyping. To generate Flag-Lrp4 transgenic mice, Flag-Lrp4 cDNA was inserted into transgene construct under human $\alpha$-skeletal actin (HSA) promoter at NotI and PacI restriction enzyme sites. The recombinant transgene construct was pronuclearly microinjected into mouse zygotes, which were introduced into pseudopregnant females. Offspring were screened for the correct genotype by PCR of tail DNA. Three-month- and 24-month-old mice were acquired from the National Institute on Aging. $\operatorname{Lrp} 4^{\mathrm{m} / \mathrm{m}}$ mice were as described previously (Weatherbee et al., 2006). Mice were backcrossed into C57BL/6 background and housed in a room with a $12 \mathrm{~h}$ light/dark cycle and ad libitum access to water and rodent chow diet (Diet 7097, Harlan Teklad). Unless otherwise indicated, both genders were used in the study and experiments were approved by the IACUC of Augusta University and Case Western Reserve University.

Reagents and antibodies. Chemicals were purchased from SigmaAldrich unless otherwise indicated. CF568-labeled $\alpha$-bungarotoxin ( $\alpha$ BTX; \#00006; 1:500-1000 for staining) was purchased from Biotium. Antibodies used were as follows: AChR $\delta$ (88B; 1:2000 for Western blot) from ThermoFisher Scientific; AChR $\varepsilon$ (ab65180; 1:2000 for Western blot), SG $\alpha$ (ab189254; 1:500 for staining and 1:2000 for Western blot) from Abcam; Ubiquitin (sc-8017; 1:1000 for Western blot), AChR $\alpha$ (sc65829; 1:1000 for Western blot), and AChR $\beta$ (sc-11371; 1:1000 for Western blot) from Santa Cruz Biotechnology; DOK7 (AF6398; 1:1000 for Western blot) from R\&D Systems; neurofilament (C28E10; 1:500 for staining) and synapsin (D12G5, 1:500 for staining) from Cell Signaling Technology; GAPDH (NB 600-501; 1:3000 for Western blot) from Novus; V5 (V8012; 1:1000 for Western blot), laminin (041M4799; 1:200 for staining) and GFP (11814460001; 1:3000 for Western blot and 1:500 for staining) from Sigma Aldrich. AlexaFluor 488 goat anti-rabbit IgG, AlexaFluor 488 goat anti-mouse IgG, horseradish peroxidase (HRP)conjugated goat anti-rabbit IgG, and goat anti-mouse IgG antibodies (1:4000 for Western blot), anti-agrin, anti-LRP4, anti-MuSK, antiphosphotyrosine, anti-Rapsyn, anti-HSP90 $\beta$, and anti-Flag antibodies were described previously (Luo et al., 2008; Zhang et al., 2008; Shen et al., 2013; Barik et al., 2014; Zhao et al., 2017).

Immunofluorescence. For NMJ staining, muscles were fixed with $4 \%$ paraformaldehyde (PFA) in PBS at $4^{\circ} \mathrm{C}$ overnight, rinsed with $0.1 \mathrm{M}$ glycine in PBS for $20 \mathrm{~min}$ and incubated with the blocking buffer $(5 \%$ BSA, $2 \%$ Triton X-100, and 5\% goat serum in PBS) for $1 \mathrm{~h}$ at room temperature. Afterward, they were incubated with the blocking buffer with primary antibodies at $4{ }^{\circ} \mathrm{C}$ overnight. After washing three times for 30 min each with $0.5 \%$ Triton X-100 in PBS, the samples were incubated with fluorescent-labeled secondary antibodies overnight at $4^{\circ} \mathrm{C}$. Samples were washed with $0.5 \%$ Triton X-100 in PBS three times for 30 min each and mounted with VECTASHIELD mounting medium (H1200) and covered with coverslip.

To prepare cross-sections, muscles were fixed with $4 \%$ PFA in PBS at $4^{\circ} \mathrm{C}$ overnight and dehydrated in $30 \%$ sucrose at $4^{\circ} \mathrm{C}$ overnight. They were cut into $25 \mu \mathrm{m}$ sections on a cryostat (HM550, ThermoFisher Scientific) at $-25^{\circ} \mathrm{C}$. Sections were incubated with the blocking buffer for $1 \mathrm{~h}$ at room temperature and then with primary antibodies at $4^{\circ} \mathrm{C}$ overnight. After washing three times for 10 min each with $0.5 \%$ Triton X-100 in PBS at room temperature, samples were incubated with fluorescentlabeled secondary antibodies overnight at $4^{\circ} \mathrm{C}$ and mounted with VECTASHIELD mounting medium. $Z$ serial images were collected with a Zeiss confocal laser-scanning microscope (LSM 700) and collapsed into a single image.

Reverse transcription-PCR analysis. Total RNA was purified from muscles with Trizol (Invitrogen) and reverse transcribed to cDNAs with GoScript reverse transcription kit (Promega). cDNAs were used as template in quantitative PCR ( $\mathrm{qPCR}$ ) in a $20 \mu \mathrm{l}$ reaction system containing SYBR GreenER qPCR mix with gene-specific primers. PCR included an initial step at $95^{\circ} \mathrm{C}(3 \mathrm{~min})$, followed by 40 cycles consisting of denaturation at $95^{\circ} \mathrm{C}(15 \mathrm{~s})$, annealing and extension at $60^{\circ} \mathrm{C}(60 \mathrm{~s})$. Gapdh was used as internal control. Primers for individual genes were as follows: Chrna (F: 5'-CTCTC GACTG TTCTC CTGCT G-3', R: 5'-GTAGA CCCAC GGTGA CTTGT A-3'); Chrnd (F: 5' -GAATG AGGAA CAAAG GCTGA 
TCC, R: 5'-GGTGA GACTT AGGGC GACAT-3'); Ache (F: 5'-GGCTC CTACT TTCTG GTTTA CGG-3', R: 5'-GGCTG CCAGG TCACT TGCTT-3'); $\operatorname{Lrp} 4$ (F: 5'-AGTCA CCGCA AGGCT GTCAT TA-3', R: 5'-GTTGG CACTA TTGAT GCTCT TGG-3'); Musk (F: 5'-ACCGT CATCA TCTCC ATCGT GT-3', R: 5' -CTCAA TGTTA TTCCT CGGAT ACTCC-3'); Sgca (F: 5'-ACTGA AGCCA CAGAC CGAGA CT-3', R: 5'-ATGAT GTAAG CCAGC AACAG AGTAA-3'); $S g c b$ (F: 5'-GAGAG CGGTC TGCTG AGGTT C-3', R: 5' -CGCTG GTGAT GGAGG TCTTG T-3'); Sgcg (F: 5'-GCTGC CTATA CCTAT TCGTT CTTCT C-3' R: 5'-CACTC TGGAG CGTAT TTCTT TGG-3'); Sgcd (F: 5'-ATTCC CACCA CAGGA GCACC ATG-3', R: 5'-GGAGC AGGAC AAAGA AATAC AGG-3'); Gapdh (F: 5'-AAGGT CATCC CAGAG CTGAA-3', R: 5'-CTGCT TCACC ACCTT CTTGA-3').

Western blot and coimmunoprecipitation assay. Western blotting and coimmunoprecipitation (co-IP) assays were performed as described previously (Shen et al., 2013; Li et al., 2016). Briefly, cells and tissues were homogenized and lysed in the cell lysis buffer containing $150 \mathrm{~mm} \mathrm{NaCl}$, 2.5 mм EDTA, 50 mм Tris-HCl, pH, 7.4, 50 mм NaF, 2\% SDS, 0.5\% sodium deoxycholate, $20 \%$ glycerol, $0.1 \%$ sodium vanadate, $1 \%$ PMSF and $1 \%$ protease inhibitor cocktail (04693159001, Sigma-Aldrich). Lysates were subjected to centrifugation at $12,000 \times \mathrm{g}$ for $10 \mathrm{~min}$ at $4^{\circ} \mathrm{C}$. Supernatants (referred as lysates) were diluted with $4 \times$ loading buffer containing $20 \%$ Tris- $\mathrm{HCl}, \mathrm{pH}, 8.8,8 \%$ SDS, $8 \% \beta$-mercaptoethanol, $0.04 \%$ bromophenol blue, $40 \%$ glycerol, and heated at $95^{\circ} \mathrm{C}$ for $10 \mathrm{~min}$. Samples were resolved by SDS-PAGE running and transferred to nitrocellulose membrane (catalog \#1620112, Bio-Rad). The membrane was blocked in $5 \%$ nonfat milk for $1 \mathrm{~h}$ and incubated in primary antibodies overnight at $4^{\circ} \mathrm{C}$. After washing with $0.1 \%$ Tween 20 in PBS 3 times for 10 min each, membranes were incubated in HRP-conjugated secondary antibodies for $1 \mathrm{~h}$ at room temperature. Immunoreactive protein bands were visualized by a kit of enhanced chemiluminescence (Pierce).

For co-IP assay, cell or tissue lysates were diluted by adding nine volumes of modified RIPA buffer $(150 \mathrm{~mm} \mathrm{NaCl}, 2.5 \mathrm{~mm}$ EDTA, $50 \mathrm{~mm}$ Tris- $\mathrm{HCl}, 50 \mathrm{~mm} \mathrm{NaF}, 0.1 \%$ sodium vanadate, $1 \%$ PMSF, and $1 \%$ protease inhibitor cocktail) and incubated with $1-2 \mu \mathrm{g}$ antibodies at $4^{\circ} \mathrm{C}$ overnight. The reaction was then incubated with $5 \mu$ l protein $A / G$ agarose beads (sc-2003, Santa Cruz Biotechnology) at $4^{\circ} \mathrm{C}$ for $4-5 \mathrm{~h}$. Proteins pulled down by beads were subjected to Western blot analysis.

Electromyography and electrophysiological recording. Mice were anesthetized with ketamine and xylazine mixture (100 and $10 \mathrm{mg} / \mathrm{kg}$ body weight, respectively) on a $37^{\circ} \mathrm{C}$ heating pad. The stimulation needle electrode (TECA, 092-DMF25-S) was inserted near the sciatic nerve of the left leg at thigh level and connected to an isolator (ISO-Flex, AMPI). The reference needle electrode was inserted into the Achilles tendon whereas the recording needle electrode was inserted into the middle of left gastrocnemius, both of which were connected to AxoPatch 200B Amplifier (Molecular Devices). Stimulation of the sciatic nerve was triggered with a series of 10 stimuli at 1, 5, 10,20, and $40 \mathrm{~Hz}$. Compound muscle action potentials (CMAPs) were recorded by Digidata 1322A and analyzed by Clampfit 9.2 software (Molecular Devices).

To study neuromuscular transmission, left hemi-diaphragm together with ribs and phrenic nerves were dissected, mounted on SYLGARD gel and perfused in oxygenated $\left(95 \% \mathrm{O}_{2}, 5 \% \mathrm{CO}_{2}\right)$ Ringer solution (in mM: $137 \mathrm{NaCl}, 5 \mathrm{KCl}, 12 \mathrm{NaHCO}_{3}, 1 \mathrm{NaH}_{2} \mathrm{PO}_{4}, 1 \mathrm{MgCl}_{2}, 2 \mathrm{CaCl}_{2}, 11$ D-glucose, $\mathrm{pH}$ 7.3) at room temperature. To record miniature endplate potentials (mEPPs), microelectrodes (CV203 BU HEADSTAGE, 20-40 $\mathrm{m} \Omega$, filled with $3 \mathrm{M} \mathrm{KCl}$ ) connected to the AxoPatch 200B Amplifier was inserted to central regions of the muscle. Recordings were performed when resting membrane potentials were at $-65 \sim-80 \mathrm{mV}$. Five recordings were performed per diaphragm, each lasting 2-3 min. Data were collected with AxoPatch 200B Amplifier and Digidata 1322A and analyzed by Clampfit 9.2 software.

In vivo twitch and tetanic force measurement. Torque muscle strength was measured on male mice as previously reported (Ingalls et al., 2004; Arpke et al., 2013; Zhao et al., 2017). Briefly, mice were anesthetized with isoflurane continuously supplied by VetFlo anesthesia system (Kent Scientific) and placed on a $37^{\circ} \mathrm{C}$ heating pad. The knees were fixed by gently pressing the knee clamps and the feet were fixed onto the footplate that was connected to the servomotor (Aurora Scientific 1300A). The angle of the footplate was adjusted to reach maximal twitch force before experiment. The sciatic nerve was exposed at thigh level and stimulated at $5 \mathrm{~mA}$ by two needle electrodes. Stimulation pulse width was $0.2 \mathrm{~ms}$ for all experiments. Tetanic contractions were induced by $300 \mathrm{~ms}$ stimuli at frequencies of 50,100,150, and $200 \mathrm{~Hz}$. There was an interval of $30 \mathrm{~s}$ between each twitch and an interval of $2 \mathrm{~min}$ between each tetanic force measurement. Twitch and tetanic forces were normalized by body weight.

AAV9 production and animal treatment. Human SGCA cDNA was amplified from pLX304-Sgca plasmid (clone HsCD00435026, DNASU by PCR primers (F: $5^{\prime}$-CCGGA ATTCG CCACC ATGGC TGAGA CACTC TTCTG GACT-3', R: 5'-GCACC GGTCC GTGCT GGTCC AGAAT GAGGG G-3') and cloned to AAV-CMV-GFP plasmid (67634, Addgene) at EcoRI and AgeI restriction enzyme sites. AAV9-SG $\alpha$-GFP and AAV9-CMV-GFP were prepared by the Viral Vector Core at Emory University Department of Neurology as previously described (Yang et al., 2017 ). Virus (30-50 $\mu \mathrm{l}$ of $\left.1-2 \times 10^{13} \mathrm{vg} / \mathrm{ml}\right)$ was delivered by intramuscular injection or by intravenous injection (via tail vein; $5 \times 10^{11} \sim 1 \times$ $10^{12} \mathrm{vg} /$ mouse).

Statistical analysis. Data were analyzed by unpaired $t$ test, one-way ANOVA (with Tukey's multiple-comparison test) and two-way ANOVA (with Bonferroni's post hoc test). Unless otherwise indicated, 10-20 NMJs or muscle fibers were quantified for each mouse. The sample size $(N)$ was based on the literature (Li et al., 2008; Wu et al., 2012; Shen et al., 2013; Barik et al., 2014; Zhao et al., 2017). Data are shown as mean \pm SEM. Statistical difference was considered when $p<0.05$.

\section{Results \\ Reduced LRP4 protein level and MuSK phosphorylation in aged mice}

In light of the critical role of agrin-LRP4-MuSK signaling in NMJ maintenance (Hesser et al., 2006; Samuel et al., 2012; Barik et al., 2014) and similar NMJ deficits (fragmented AChR clusters, reduced AChR density, and increased denervation) between aged mice and conditional mutant mice lacking agrin and LRP4 in adult animals, we determined whether levels of agrin signaling proteins were altered in muscles of aged mice. Because agrin signaling proteins are concentrated at the NMJ (Merlie and Sanes, 1985), we focused on synaptic region (SR), which is localized in the central region of muscle fibers (Fig. 1A). As shown in Figure $1 B$, mRNAs of AChR subunits and AChE were enriched in the SR region compared with the nonsynaptic region (NSR), which was also supported by Western blot. Western blot analysis showed similar levels of $\mathrm{AChR} \alpha, \beta$ and $\varepsilon$-subunits between muscles from 3 - and 24-month-old mice, with the exception of an increased protein level of $\delta$-subunit (Fig. $1 C, D$ ), indicating that the protein levels of AChR subunits were not reduced among aging, consistent with previous report (Ibebunjo et al., 2013). In contrast, LRP4 protein level was reduced by 50\% in 24-month-old (24 M) SRs compared with 3-month-old (3 M) SRs. This effect was specific because levels of agrin, MuSK, DOK7, rapsyn were similar between the young and old samples (Fig. 1E,F). Concomitantly, MuSK phosphorylation was reduced in aged muscles (Fig. $1 G, H)$, indicating compromised MuSK activation. These results suggest that impaired agrin signaling in aged muscles is probably due to loss of Lrp4 protein.

\section{Diminished NMJ deficits in aged mice by LRP4 expression}

If loss of LRP4 contributes to NMJ deficits in aged mice, expressing LRP4 should be able to diminish the deficits. To test this hypothesis, we generated transgenic mice where the expression of Flag-tagged LRP4 is driven by muscle-specific HSA promoter (Flag-Lrp4 transgenic mice hereafter; Fig. 2A). Expression of the transgene Flag-Lrp4 was dependent on myotube formation after transfection in C2C12 myoblast (Fig. 2B), in agreement with pre- 
A

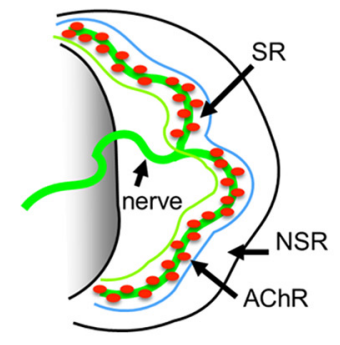

E

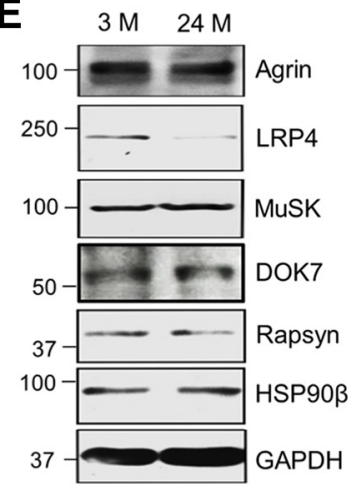

B

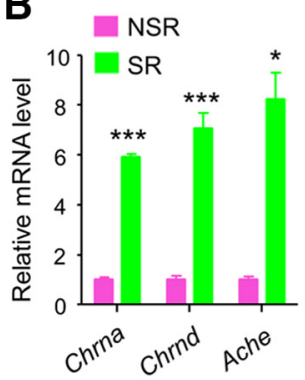

F

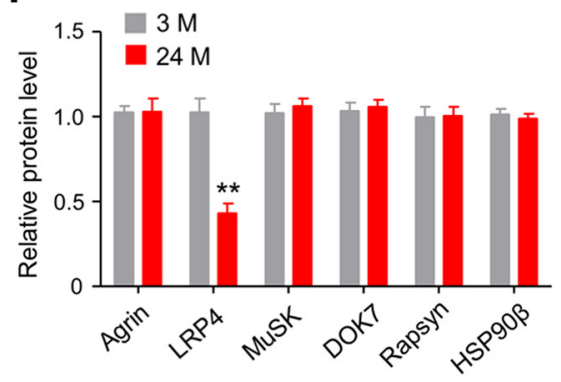

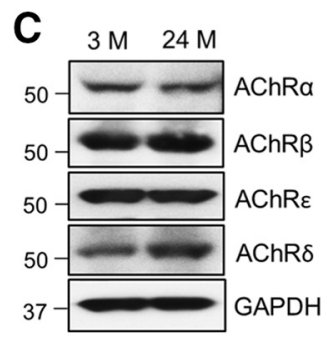

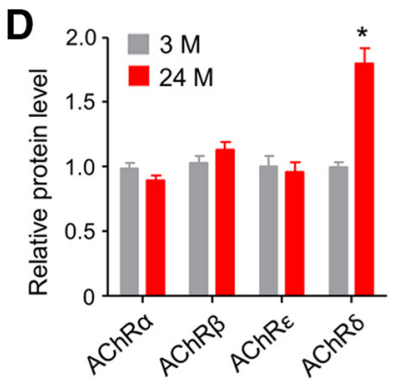

G

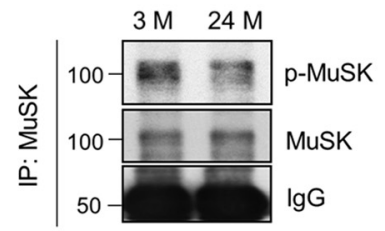

H

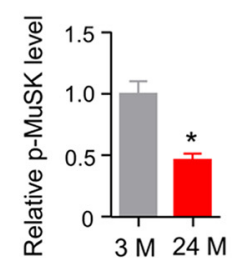

Figure 1. Reduced LRP4 level and MuSK phosphorylation in aged mice. $A$, Diagram of a hemi-diaphragm to illustrate SR and NSR. $\boldsymbol{B}$, Enriched AChR mRNA (left) and protein (right) in SR. $t_{(4)}=$ $34.4{ }^{* * *} p=4.2 \mathrm{E}-6$ for Chrna; $t_{(4)}=9.6,{ }^{* * *} p=0.00067$ for Chrnd; $t_{(4)}=6.78,{ }^{*} p=0.019$ for $A$ che; $N=3$ mice per group, unpaired $t$ test. $\boldsymbol{C}$, Increased AChR- $\delta$ protein level in aged muscles. $\boldsymbol{D}$, Quantification of data in $\boldsymbol{C} . t_{(4)}=5.5,{ }^{*} p=0.021$ for AChR $\delta$. $\boldsymbol{E}$, Reduced LRP4 protein level in aged muscles. $\boldsymbol{F}$, Quantification of data in $\boldsymbol{E}$. $t_{(4)}=5.9$, ${ }^{* *} p=0.004$. $\boldsymbol{G}$, Reduced tyrosinephosphorylation of MuSK in aged muscles. $\boldsymbol{H}$, Quantification of p-MuSK over MuSK in $\boldsymbol{G}$. $t_{(4)}=4.7,{ }^{*} p=0.019$. $\boldsymbol{C}-\boldsymbol{H}$, SRs of diaphragms of indicated ages were homogenized and subjected to Western blotting. $N=3$ mice per group, unpaired $t$ test.

vious reports (van der Ven et al., 1992; Brennan and Hardeman, 1993). Western blot analysis indicated that Flag-Lrp4 is expressed specifically in skeletal muscles, but not in other tissues and organs (Fig. 2C). Importantly, crossing Flag-Lrp4 transgenic mice was able to fully restore the declined MuSK phosphorylation level (Fig. 2D) and rescue NMJ deficits in $\operatorname{Lrp} 4^{\mathrm{m} / \mathrm{m}}$ mice that otherwise fail to form the NMJ because the lack of $\operatorname{Lrp} 4$ (Fig. 2E), indicative of respectable in vivo function of the $\operatorname{Lrp} 4$ transgene allele.

Hindlimb muscles as well as the diaphragm are vulnerable to aging (Valdez et al., 2012). Tibialis anterior (TA) muscles were stained whole-mount with CF568 $\alpha$-bungarotoxin ( $\alpha$-BTX, red) to label AChR and anti-neurofilament/synapsin (NF/Syn) antibodies (visualized by AlexaFluor 488 goat anti-rabbit IgG, green) to label axon terminals. In $3 \mathrm{M}$ mice, NMJs appeared as characteristic pretzel-like structures and AChR clusters were fully innervated (Fig. $3 A, B)$. In contrast, in $24 \mathrm{M}$ mice, a majority $(\sim 80 \%)$ of AChR clusters were fragmented and denervated (Fig. $3 A-E$ ). We quantified the innervation of AChR clusters as previously described (Macpherson et al., 2015; Zhao et al., 2017): fully innervated AChR clusters (80-100\% neve-endplate overlap), partially or fully denervated AChR clusters ( $<80 \%$ overlap). Fully innervated AChR clusters were reduced by $\sim 50 \%$ in $24 \mathrm{M}$ mice. These results were in accordance with previous studies (Valdez et al., 2010). Interestingly, the percentages of fully innervated endplate were increased from $51.1 \%$ in $24 \mathrm{M}$ control mice to $72.2 \%$ in $24 \mathrm{M}$ Flag-Lrp4 transgenic mice $\left(24 \mathrm{M}-\operatorname{Lrp} 4 ; F_{(2,12)}=69.4, p=\right.$ 0.0001; Fig. $3 A, C)$. On the other hand, NMJ fragmentation was improved in transgenic mice compared with control mice at $24 \mathrm{M}$ (Fig. $3 B, D$,E). Fragmentation numbers per NMJ in $24 \mathrm{M}$ transgenic mice were reduced to $4.7 \pm 1.3$, from control mice at the same age $\left(7.3 \pm 0.8 ; F_{(2,12)}=29.3, p=0.0022\right.$; Fig. $\left.3 B, D\right)$ and the percentages of fragmented NMJ were reduced to $52 \pm 10 \%$ from
$75 \pm 11 \%$ in aged mice $\left(F_{(2,12)}=58.1, p=0.0065\right.$; Fig. $\left.3 B, E\right)$. The AChR intensity was also increased by $48 \%$ in $24 \mathrm{M}-\operatorname{Lrp} 4$ mice $\left(F_{(2,12)}=29.3, p=0.0089\right.$; Fig. $\left.3 B, F\right)$. These results suggest that Lrp4 expression is able to mitigate NMJ fragmentation and poor innervation in aged mice.

\section{Improved neuromuscular transmission and muscle function in aged Flag-Lrp4 transgenic mice}

To determine whether $\operatorname{Lrp} 4$ expression improves neuromuscular transmission, we measured CMAP, action potentials that are triggered by 10 consecutive nerve stimuli. CMAP amplitudes between first and 10th stimuli were similar among young and old groups at 1,5 , and $10 \mathrm{~Hz}$ of stimulation frequency, just as previously reported (Shen et al., 2013; Willadt et al., 2016; Zhao et al., 2017). However, at stimulation frequencies 20 and $40 \mathrm{~Hz}$, CMAP amplitudes at 10th stimuli versus first stimuli were smaller in $24 \mathrm{M}$ mice compared with $3 \mathrm{M}$ mice (Fig. $4 A-C$ ). At $40 \mathrm{~Hz}$, CMAP reduction was detectable even at fourth stimulation (Fig. $4 B$ ). These results suggest compromised neuromuscular transmission in aged muscles. Interestingly the age-dependent reduction in CMAP amplitudes was diminished in Flag-Lrp4 transgenic mice compared with control mice of the same age, indicative of a beneficial effect by $L r p 4$ expression. In addition, we measured mEPPs, local depolarizing potentials elicited by spontaneously released ACh. As shown in Figure 4D-F, mEPP amplitudes were reduced in $24 \mathrm{M}$ mice, supporting the notion of compromised neuromuscular transmission. Again, this reduction was attenuated in Flag-Lrp4 transgenic mice $\left(F_{(2,9)}=18.7\right.$, $p=0.035$; Fig. $4 D, F)$. These results demonstrate that neuromuscular transmission is compromised in aged mice, which could be diminished by Lrp4 expression. Aged muscle fibers were smaller and had more centrally localized nuclei, a sign of 
A

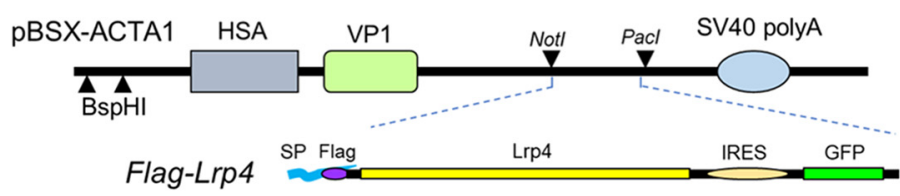

B Differentiation (Day)

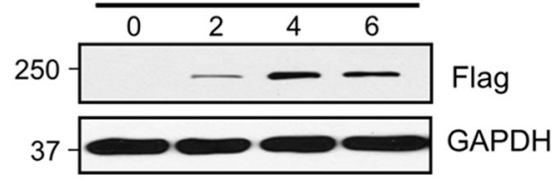

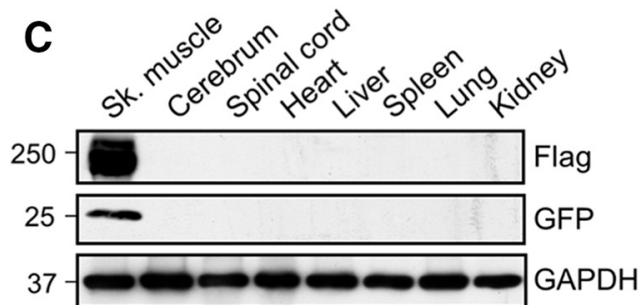

E

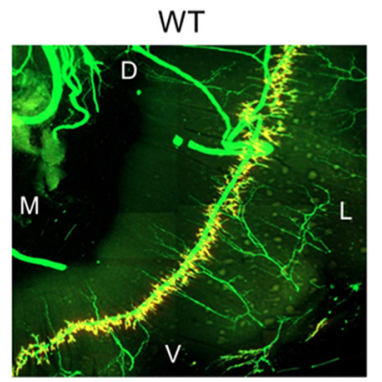

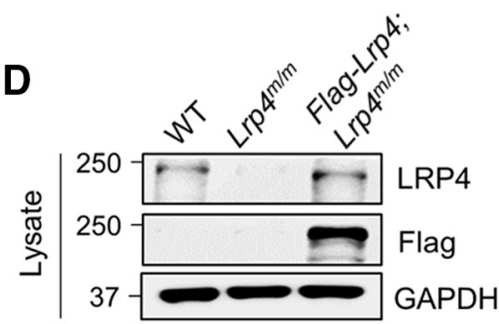

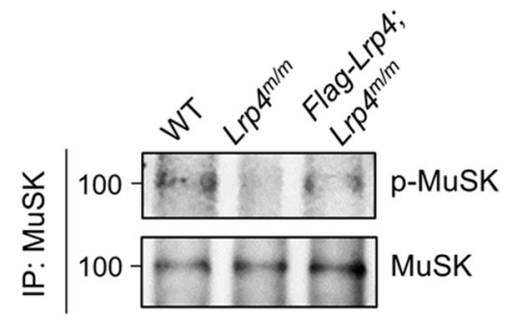

Figure 2. Specific expression of Lrp4 in muscles of Flag-Lrp4 transgenic mice.A, HSA-Lrp4 structure. Flag-Lrp4 was inserted between Notl and Pacl in pBSX-ACTA1. SP, Signal peptide; IRES, internal ribosomal entry site; VP1, polyomavirus capsid protein. B, Flag-Lrp4 transgene expression in myotubes, not in myoblasts. C2C12 myoblasts were transfected with Flag-Lrp4 construct and examined for expression in transfected myoblasts and myotubes. C, Flag-Lrp4 expression in skeletal muscles but not other tissues of Flag-Lrp4 transgenic mice. D, Amelioration of MuSK phosphorylation in $L r p 4^{m / m}$ muscle by Flag-Lrp4 transgene. $E$, Restoration of NMJ deficits in $L r p 4^{m / m}$ mice by Flag-Lrp4 transgene. Shown were diaphragms of indicated genotypes that were whole-mount stained with CF568 $\alpha$-BTX (red) and anti-NF/Syn antibodies (visualized by AlexaFluor 488 goat anti-rabbit lgG; green). D, Dorsal; V, ventral; L, lateral; M, medial. Scale bar $500 \mu \mu$ m.

muscle regeneration (Fig. $5 A-C$ ). These two phenotypes were diminished by Lrp4 expression. In agreement, Flag-Lrp4 expression increased twitch and tetanic forces in aged mice (Fig. $5 D-F)$, suggesting improved muscle function.

\section{Reduced LRP4 protein stability in aged mice}

Next, we explored mechanisms of low LRP4 protein level in muscles of aged mice. A recent report showed increased mRNA levels of Lrp4 and Musk in gastrocnemius muscles of 24M-27M mice (Ibebunjo et al., 2013). Genes critical for NMJ formation and maintenance are transcribed specifically in subsynaptic nuclei (Merlie and Sanes, 1985). We extracted RNAs from SRs as described in Figure 1 and performed RT-PCR. As shown in Figure $6 A$, both Lrp4 and Musk mRNA levels were higher in synaptic regions of $24 \mathrm{M}$ mice compared with those of $3 \mathrm{M}$ mice. This result suggests that reduced protein level of LRP4 is unlikely due to a problem at transcription level, rather a posttranscriptional mechanism. We determined the pathway of LRP4 degradation in muscle cells. C2C12 myotubes were treated with chloroquine (50 $\mu \mathrm{M})$, an inhibitor of lysosome degradation or MG132 (30 $\mu \mathrm{M})$, an inhibitor of proteasome degradation for $6 \mathrm{~h}$. As shown in Figure 6, $B$ and $C$, MG132 increased LRP4 protein level whereas chloroquine had no detectable effect, suggesting that LRP4 is mainly degraded by proteasomes in muscle cells. To determine whether this is the case in vivo, muscle samples from $3 \mathrm{M}$ and $24 \mathrm{M}$ mice were lysed and immunoprecipitated with anti-LRP4 antibody and blotted for ubiquitin. The amount of ubiquitinated LRP4 (normalized by total LRP4) was increased in $24 \mathrm{M}$ mice com- pared with $3 \mathrm{M}$ mice (Fig. $6 D, E$ ). The above results implicate increased LRP4 degradation by proteasome in aged muscles.

\section{Requirement of SG $\alpha$ for LRP4 protein stability}

To investigate the molecular mechanism regulating LRP4 protein stability in muscles, we screened for proteins that interact with LRP4 and that have been implicated in neuromuscular disorders, and identified $\mathrm{SG} \alpha$. SG $\alpha$ is a member of the sarcoglycan complex consisting of $\mathrm{SG} \alpha, \beta, \gamma$, and $\delta$ in muscles. The SG complex is a subcomplex of the DGC that also includes the dystroglycans, syntrophin, and sarcospan. The DGC complex links the interior cytoskeleton to the ECM and is important for sarcolemma integrity. As shown in Figure 7A, in HEK293 cells, Flag-LRP4 coprecipitated with cotransfected $\mathrm{SG} \alpha$, but not SG $\delta$, indicating the specificity of the interaction. To demonstrate that LRP4 interacts with SG $\alpha$ in vivo, muscle homogenates were from Flag-Lrp4 transgenic mice and incubated with anti-SG $\alpha$ antibody and normal IgG (as control) and resulting precipitates were probed with anti-Flag and anti-SG $\alpha$ antibody. Flag-LRP4 was present in the immunocomplex precipitated by anti-SG $\alpha$ antibody (Fig. 7B). Interestingly, $\mathrm{SG} \alpha$ was reduced in aged muscles by $47 \%$ and $43 \%$ at mRNA (Fig. 7C) and protein (Fig. 7D) levels, respectively. At muscle cross-sections, SG $\alpha$ was associated with muscle membrane and present at the NMJ (labeled by $\alpha$-BTX) in $3 \mathrm{M}$ mice. In muscles of $24 \mathrm{M}$ mice, $\mathrm{SG} \alpha$ staining was coarse; there were areas that were labeled by $\alpha$-BTX, but not anti-SG $\alpha$ antibody (Fig. 7E, arrowhead). The observations suggest potential SG $\alpha$ loss of function in aged muscles. Next, we determined whether $\mathrm{SG} \alpha$ may 
A

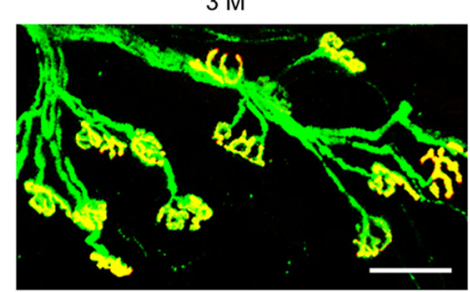

$24 \mathrm{M}$

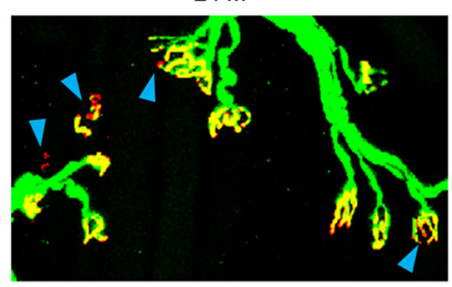

$24 \mathrm{M}-\mathrm{Lrp} 4$

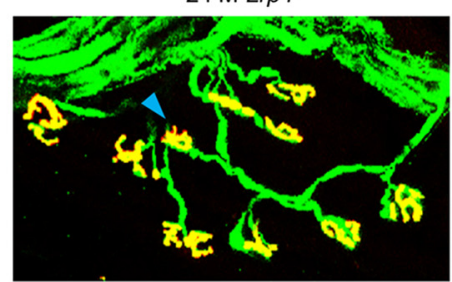

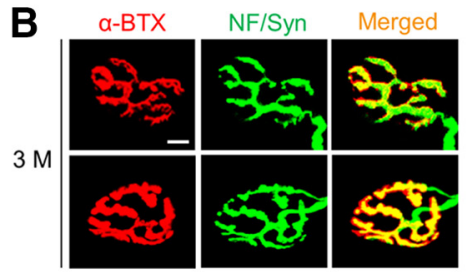
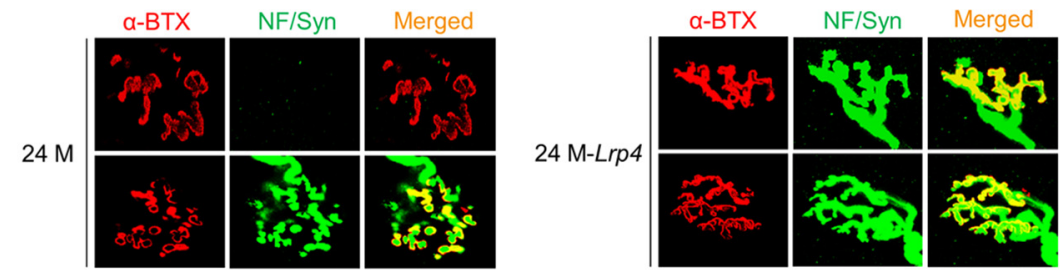

C
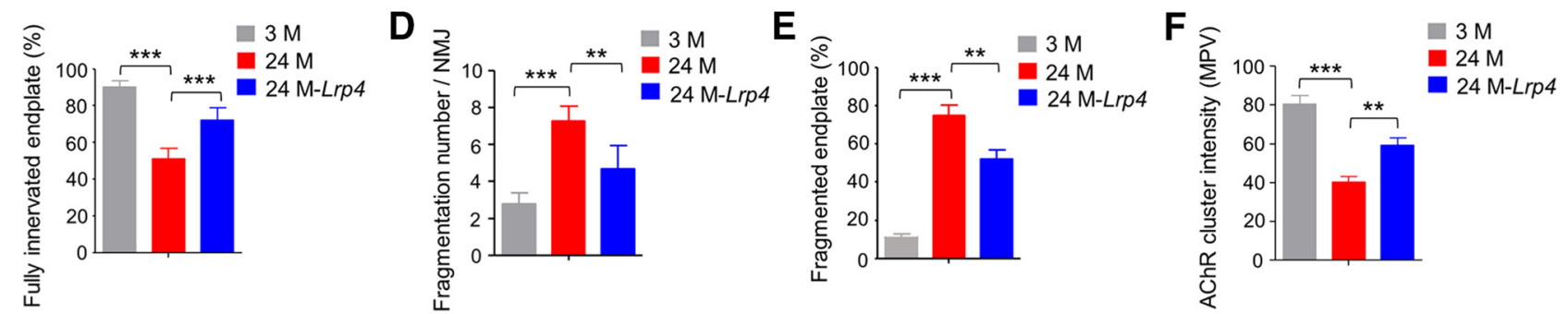

Figure 3. Diminished NMJ morphological deficits in aged mice by Lrp4 expression. $A$, Reduced fragmentation and improved innervation. Shown were TA muscles of mice at different ages and indicated genotypes, whole-mount stained with CF568 $\alpha$-BTX (red) and anti-NF/Syn antibodies (visualized by AlexaFluor 488 goat anti-rabbit lgG; green). Blue arrowhead, Denervated or partially innervated endplate. Scale bar, $50 \mu \mathrm{m}$. B, Enlarged images of individual endplates. Scale bar, $10 \mu \mathrm{m}$. $\boldsymbol{C}-\boldsymbol{F}$, Quantitative analysis of data in $\boldsymbol{A}$. $\boldsymbol{C}$, Rescue of denervation in aged mice by $\mathbf{L r p 4}$ expression; $F_{(2,12)}=69.4,{ }^{* * *} p=0.0001$. D, Rescue of fragmentation number in aged mice by Lrp4 expression; $F_{(2,12)}=29.3,{ }^{* * *} p=0.0001$, ${ }^{* *} p=0.0022$. $E$, Rescue of fragmented endplate percentage in aged mice by Lrp4 expression; $F_{(2,12)}=58.1,{ }^{* * *} p=0.0001,{ }^{* *} p=0.0065$. $\boldsymbol{F}$, Rescue of reduced AChR cluster intensity in aged mice by Lrp4 expression; $F_{(2,12)}=29.3,{ }^{* * *} p=0.0001,{ }^{* *} p=0.0089 ; N=5$ mice per group, one-way ANOVA.

A
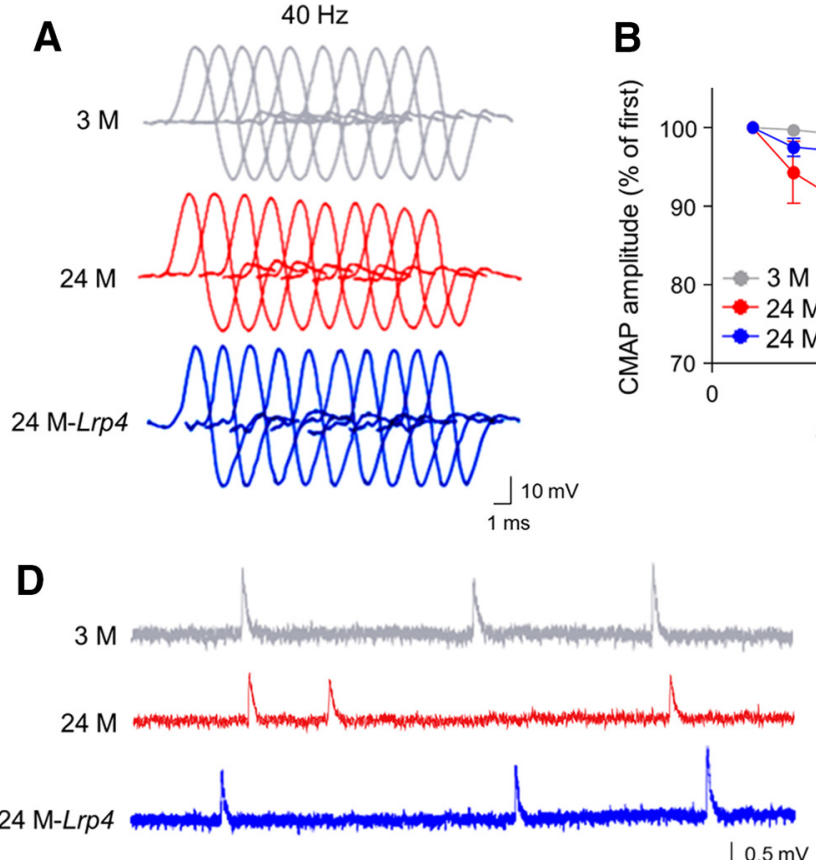

B

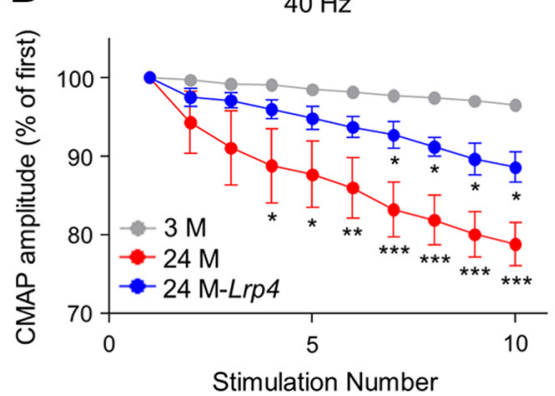

Stimulation Number

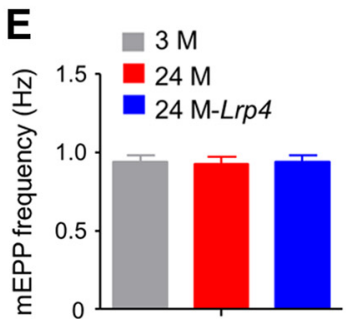

C
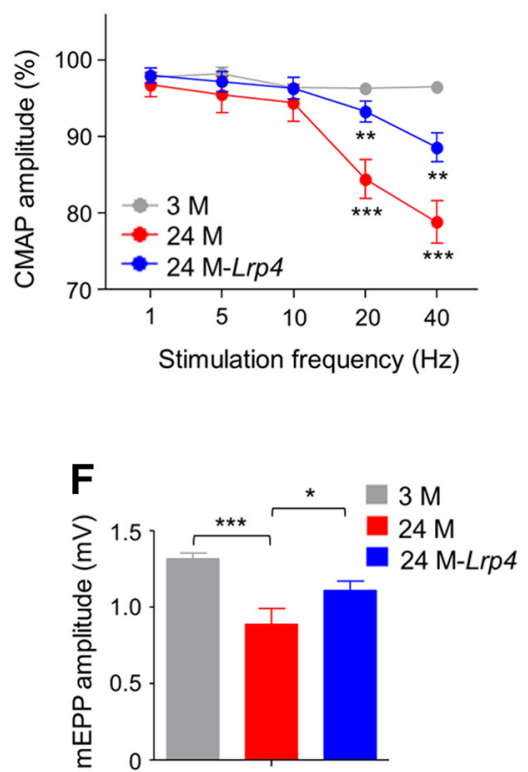

Figure 4. Improved neuromuscular transmission in aged mice by $L r p 4$ expression. $A, B$, Reduced ratio of 2nd-10th CMAP amplitudes over the first CMAP amplitude at $40 \mathrm{~Hz}$ stimulations. $A$, Representative traces; $\boldsymbol{B}$, quantitative data; $F_{(2,90)}=62.4,{ }^{*} p<0.05,{ }^{* *} p<0.01,{ }^{* * *} p<0.001 . N=4$ mice per group, two-way ANOVA. $\boldsymbol{C}$, Frequency-dependent CMAP reduction. Shown were ratios of 10th over first CMAP amplitudes; $F_{(2,45)}=24.1,{ }^{* *} p<0.01,{ }^{* * *} p<0.001 ; N=4$ mice per group, two-way ANOVA. $D-F$, Increased mEPP amplitudes of aged mice by $L r p 4$ expression. $\boldsymbol{D}$, representative mEPP traces. $\boldsymbol{E}$, Comparable mEPP frequencies. $\boldsymbol{F}$, Increased mEPP amplitudes in $24 \mathrm{M}-\mathrm{Lrp} 4$ mice compared with $24 \mathrm{M}$ mice; $F_{(2,9)}=18.7,{ }^{* * *} p=0.0005,{ }^{*} p=0.035 ; N=4$ mice per group, one-way ANOVA. 
A

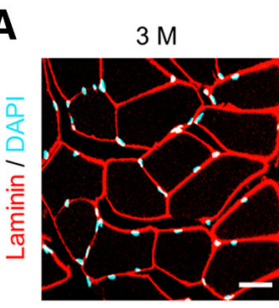

$24 \mathrm{M}$

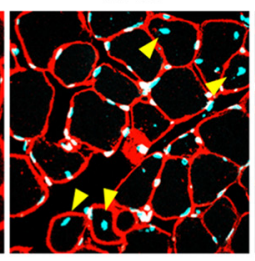

$24 \mathrm{M}-L r p 4$

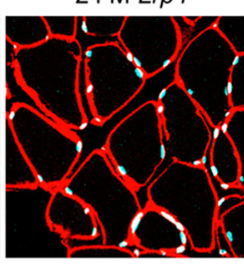

B

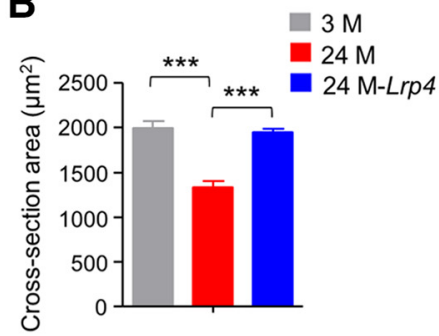

C

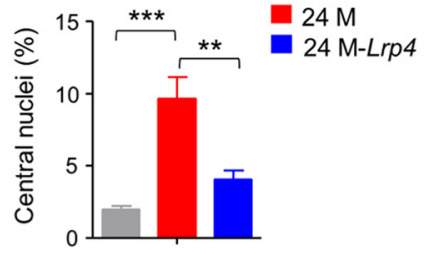

D
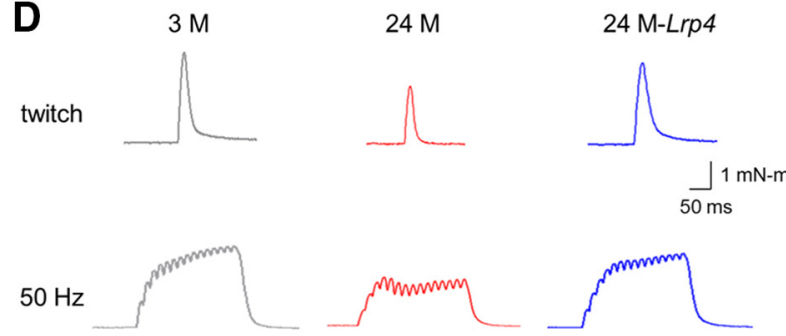

$150 \mathrm{~Hz}$

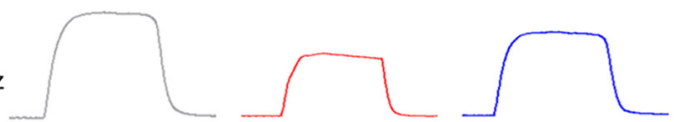

$\underset{100 \mathrm{~ms}}{2 \mathrm{mN}-\mathrm{m}}$<smiles>CC1CCCC1</smiles>

$24 \mathrm{M}-\operatorname{Lrp} 4$

$\mathbf{E}$

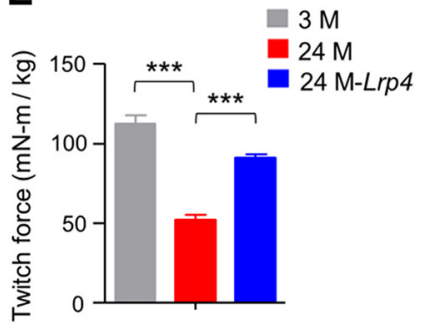

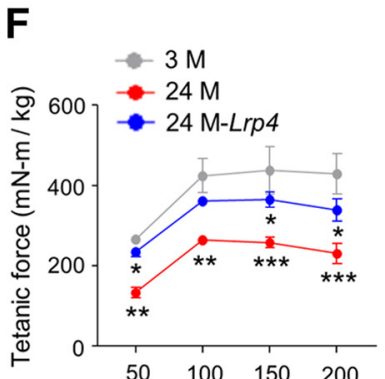

Stimulation frequency $(\mathrm{Hz})$

Figure 5. Restored muscle size and strength in aged mice by Lrp4 expression. $\boldsymbol{A}$, Increased cross-section area and reduced central nuclei in aged muscle by $L$ rp 4 expression. Cross-sections of TA muscle were stained with laminin antibody (red) and DAPI (blue). Yellow arrowhead, central nuclei. Scale bar, $20 \mu \mathrm{m} . \boldsymbol{B}$, Increased cross-section area in aged mice by $L r p 4$ expression; $F_{(2,9)}=31.1$, ${ }^{* * *} p=0.0002,{ }^{* * *} p=0.0003$. C, Reduced central nuclei in aged mice by Lrp4 expression; $F_{(2,9)}=17.4,{ }^{* * *} p=0.0008,{ }^{* *} p=0.0063 ; N=4$ mice per group, one-way ANOVA. $D$, Representative twitch (top) and tetanic force at 50 and $150 \mathrm{~Hz}$ (bottom) by sciatic nerve stimulation. $\boldsymbol{E}$, Rescue of reduced twitch force in aged mice by $L \mathrm{rp} 4$ expression; $F_{(2,9)}=70.9, * * * p=0.0001 . \boldsymbol{F}$, Rescue of reduced tetanic force in aged mice by Lrp4 expression; $F_{(2,36)}=33.6,{ }^{*} p<0.05,{ }^{* *} p<0.01,{ }^{* * *} p<0.001 ; N=4$ mice per group, two-way ANOVA.

A

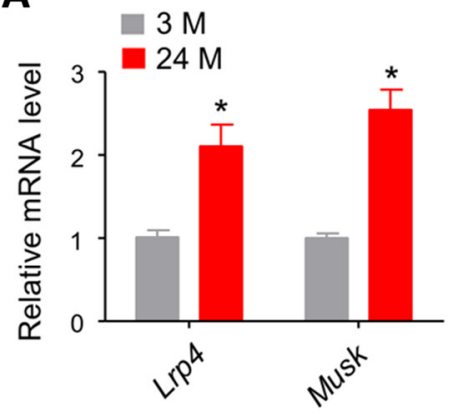

B

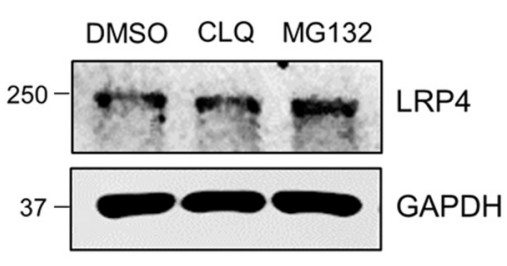

C

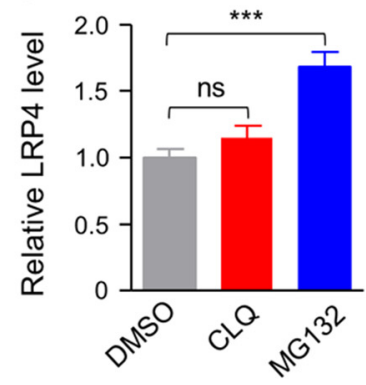

D IP: Normal IgG IP: Anti-LRP4

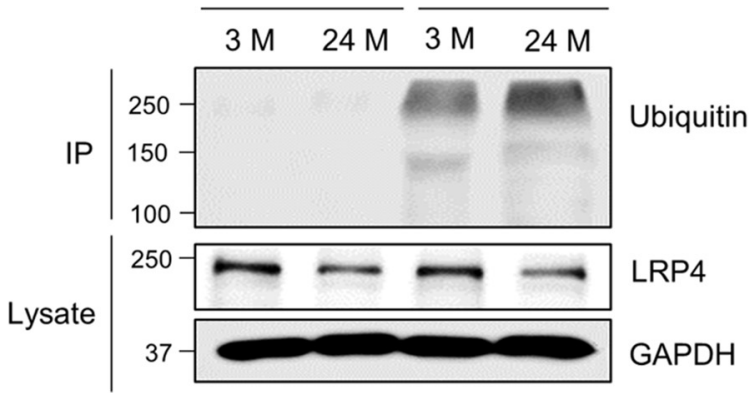

E

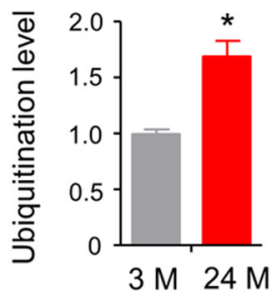

Figure 6. Increased LRP4 ubiquitination in aged mice. $A$, Increased $L r p 4$ mRNA levels in synaptic regions in aged mice; $t_{(4)}=3.9,{ }^{*} p=0.017$ for $L r p 4 ; t_{(4)}=6.04,{ }^{*} p=0.019$ for Musk, $N=3$ mice per group, unpaired $t$ test. $\boldsymbol{B}$, Increased LRP4 protein level in MG132-treated $\left(2 C 12\right.$ myotubes, but not chloroquine (CLQ)-treated myotubes. $C$, Quantification of data in $\boldsymbol{B} ; F_{(2,6)}=50.4$, ${ }^{* * *} p=$ $0.0002 ; N=3$, one-way ANOVA. $\boldsymbol{D}$, Increased LRP4 ubiquitination in synaptic regions of aged muscles. Ubiquitinated proteins were isolated by anti-LRP4 antibody and probed with anti-Ubiquitin antibody. $\boldsymbol{E}$, Quantification of data in $\boldsymbol{D} ; t_{(4)}=4.6,{ }^{*} p=0.031 ; N=3$ mice per group, unpaired $t$ test. 

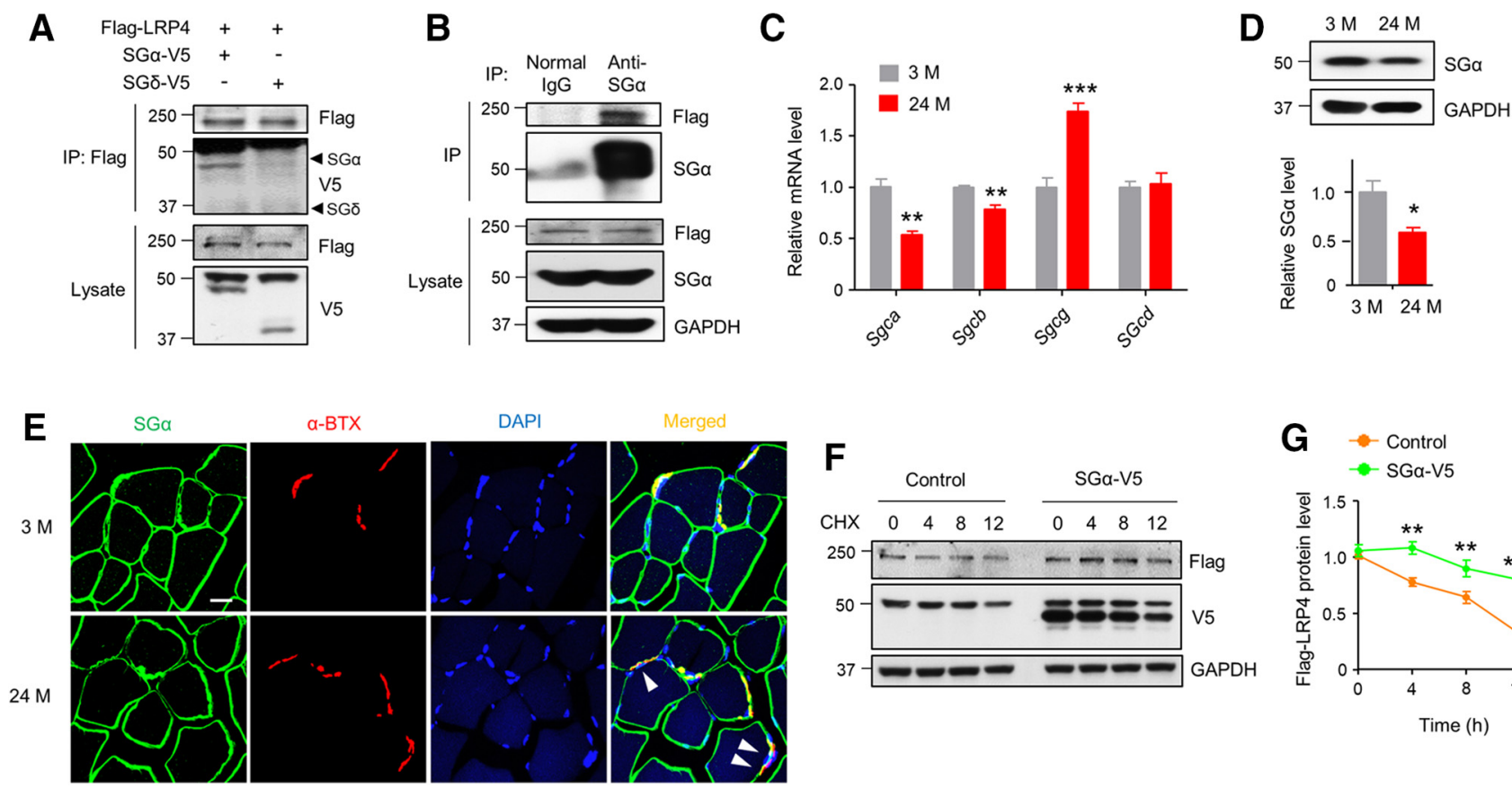

Figure 7. Increasing LRP4 protein stability by SG $\alpha$. A, LRP4 interaction with SG $\alpha$, but not SG $\delta$. Flag-LRP4 was precipitated from HEK293 cells cotransfected with SG $\alpha$-V 5 or SG $\delta$-V 5 and probed with anti-V5 antibody. Lysates were probed with the same antibodies as control. B, In vivo interaction between LRP4 and SG $\alpha$. Homogenates were prepared from muscles of Flag-Lrp4 transgenic mice and subjected to IP with anti-SG $\alpha$ antibody. Immunocomplex was probed with anti-Flag and SG $\alpha$ antibodies. $C$, mRNA expression of sarcoglycan complex molecules in diaphragm synaptic region; $t_{(4)}=9.97,{ }^{* *} p=0.0026$ for Sgca; $t_{(4)}=8.87,{ }^{* *} p=0.0039$ for Sgcb; $t_{(4)}=10.8,{ }^{* * *} p=0.0004$ for Sgcg; $N=3$ mice per group, unpaired $t$ test. $\boldsymbol{D}$, Reduced SG $\alpha$ protein level in aged mice. Top, Representative blots. Bottom, Quantitative data; $t_{(4)}=5.66,{ }^{*} p=0.015 ; N=3$ mice per group, unpaired $t$ test. $E$, Discontinuous staining of $S G \alpha$ in aged TA muscles. White arrowhead, NMJs identified by $\alpha$-BTX with discontinuous SG $\alpha$ staining. Scale bar, $20 \mu \mathrm{m}$. $\boldsymbol{F}, \boldsymbol{G}$, Increased LRP4 stability in HEK293 cells expressing SG $\alpha$. HEK293 cells were transfected with Flag-LRP4 without (control) or with SG $\alpha$-V5 and incubated with CHX. Flag-LRP4 levels were analyzed at indicated times. $\boldsymbol{F}$, Representative blot; $\boldsymbol{G}$, quantitative data; $F_{(1,16)}=56.5,{ }^{* *} p=0.0021$ and $0.0095,{ }^{* * *} p=$ $0.0001 ; N=3$, two-way ANOVA.

increase LRP4 stability by characterizing LRP4 degradation in cells cotransfected with SG $\alpha$-V5 or empty vector (as control). In the presence of cycloheximide (CHX; $50 \mu \mathrm{g} / \mathrm{ml})$ to block protein synthesis, LRP4 degraded slower in cells expressing SG $\alpha$ than in control cells. Twelve hours after CHX treatment, 77\% of LRP4 remained detectable in the presence, whereas in contrast, $>50 \%$ LRP4 was degraded in the absence of SG $\alpha$ (Fig. $7 F, G$ ). Altogether, these results demonstrate that $\mathrm{SG} \alpha$ is required for LRP4 stability in muscle cells and suggest a mechanism for lower levels of LRP4 in aged mice.

\section{Alleviation of neuromuscular aging by AAV-SG $\alpha$}

Our hypothesis predicts that increasing $\mathrm{SG} \alpha$ levels may increase LRP4 stability in aged muscles and thus ameliorate NMJ aging. To test this, we generated adeno-associated virus (AAV)expressing human SGCA (AAV9-SG $\alpha$-GFP) by subcloning human SGCA into AAV-CMV-GFP (between EcoRI and AgeI sites; Fig. 8A). As shown in Figure 8B, SG $\alpha$ was expressed in HEK293 cells transfected with the recombinant construct. After virus package and purification, we injected these AAVs $\left(5 \times 10^{11} \sim 1 \times\right.$ $10^{12} \mathrm{vg} /$ mouse) into $24 \mathrm{M}$ mice and looked for GFP labeled muscle fibers. As shown in Figure 8, $C$ and $D, 90 \%$ or more of the muscle fibers were GFP-positive in AAV9-GFP-and AAV-SG $\alpha$ GFP-infected muscles, respectively. This result indicates high infection rates of muscle fibers by AAV9 viruses. The slightly lower infection efficiency of AAV9-SG $\alpha$-GFP may be due to large cargo of SG $\alpha$ (Wu et al., 2010b). We analyzed LRP4 levels 6 weeks after intravenous injection. As shown in Figure 8, $E$ and $F$, LRP4 protein levels were increased in aged muscles infected with AAV9SG $\alpha$-GFP compared with AAV9-GFP infected muscles. This was associated with a reduction in ubiquitinated LRP4 (Fig. 8E,G).
Interestingly, in addition to the dominant, smear bands at 210 $\mathrm{kDa}$ and above (predicted from calculated molecular weight), a lower band was detected in precipitates with anti-LRP4 antibody (Figs. 6D, 8E, respectively). The identity of this band is unclear and may represent an isoform of LRP4 or cleaved product. Because it was not present when total muscle lysates were probed with anti-LRP4 antibody (Figs. $1 E, 6 D$ ), but only detectable in immunoprecipitated samples, we speculate that the lower band may be generated by a ubiquitin-dependent cleavage. Nevertheless, our results indicate that restoring SG $\alpha$ in aged muscles elevated LRP4 levels by reducing LRP4 degradation.

Next, we compared NMJs of aged mice after viral injection. There were more endplates in TA that were fully innervated in 24 $\mathrm{M}$ mice 6 weeks after intramuscular injection of AAV9-SG $\alpha$-GFP (24M-SG $\alpha$ ) compared with mice injected with AAV9-GFP (24M-GFP; increased from 49.1 to $69.5 \%, F_{(2,12)}=29, p=$ 0.0051; Fig. $9 A-C)$. NMJ fragment numbers and percentage of fragmented endplates were reduced by AAV9-SG $\alpha$-GFP (fragment numbers: $7.6 \pm 0.6$ for AAV9-GFP vs $4.9 \pm 1.3$ for AAV9$\mathrm{SG} \alpha$-GFP, $F_{(2,12)}=25.8, p=0.0023$; fragmented NMJs: $76.6 \pm$ $10.7 \%$ vs $49.4 \pm 5.9 \%$ for AAV9-GFP and AAV9-SG $\alpha$-GFP, respectively; $F_{(2,12)}=93, p=0.0003$; Figure $\left.9 B, D, \mathrm{E}\right)$. Additionally, AChR cluster intensity was increased by $52.6 \%$ in aged mice treated with AAV9-SG $\alpha$-GFP compared with AAV9-GFP control $\left(F_{(2,12)}=35.9, p=0.0028\right.$; Fig. $\left.9 F\right)$. Functionally, CMAPs were improved in aged muscles after viral expression of $\mathrm{SG} \alpha$. The 10th to first ratios of CMAP at 20 and $40 \mathrm{~Hz}$ of stimulation were 82.6 and $78.5 \%$ in GFP group, which were increased to 90.5 and $87.1 \%$ in SG $\alpha$ group (Fig. 10A-C). mEPP amplitudes were increased in $\mathrm{SG} \alpha$ group compared with GFP group (Fig. 10D-F). Moreover, similar to Lrp4 overexpression, improvement was observed in 
A

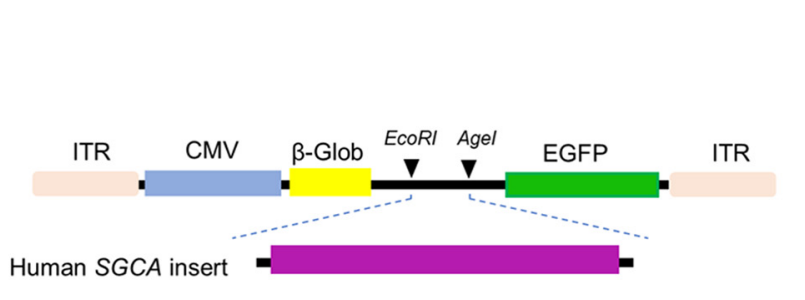

B

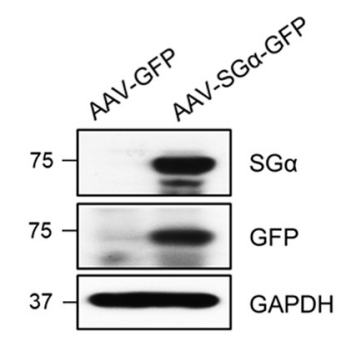

C
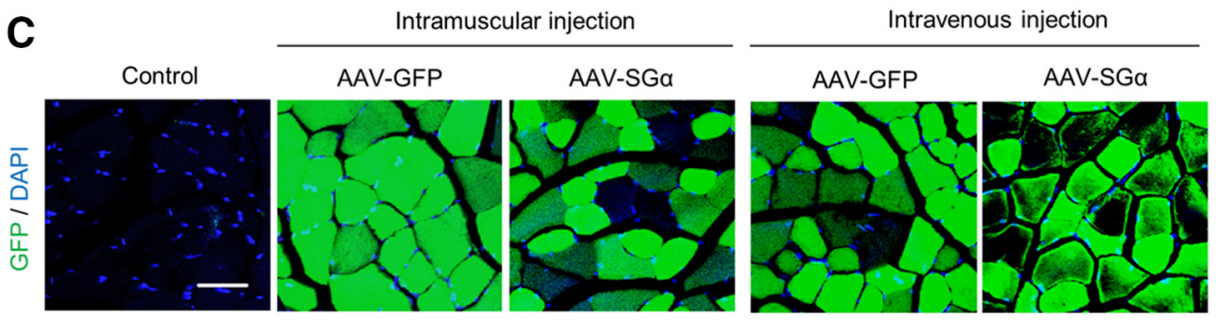

\section{$E$}

E

IP: Normal IgG IP: Anti-LRP4

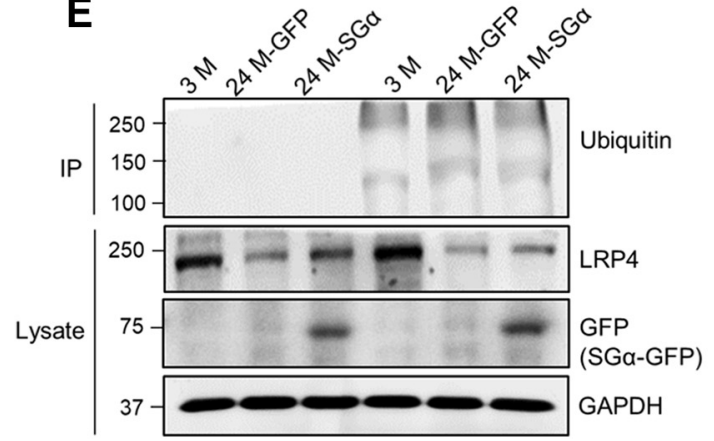

F

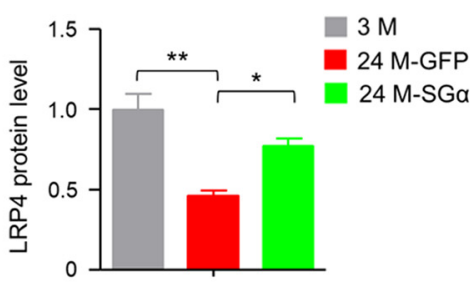

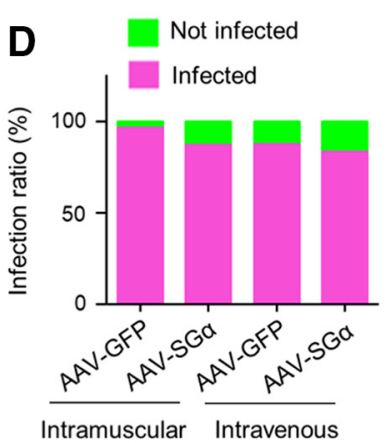

G

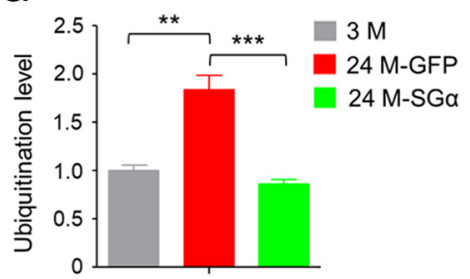

Figure 8. Increased LRP4 level with reduced ubiquitination in aged muscles by SG $\alpha$ expression. $\boldsymbol{A}$, Diagram of AAV9-SG $\alpha$-GFP construct. Human SGCA was inserted at N-terminus of GFP as a fusion protein. ITR, Inverted terminal repeats; CMV, cytomegalovirus promoter; $\beta$-Glob, $\beta$-globulin intron. $B$, SG $\alpha$ expression in HEK293 cells transfected with AAV9-SG $\alpha$-GFP. C, Expression of GFP in muscles after intramuscular and intravenous injection with indicated AAV. Shown were TA cross-sections. $\boldsymbol{D}$, High infection rates by AAV9-expressing SG $\alpha$-GFP. $\boldsymbol{E}$, Increased protein level and reduced ubiquitination of LRP4 by $S G \alpha$ expression. Muscles were isolated 6 weeks after intravenous injection of AAV9-expressing $S G \alpha$. $\boldsymbol{F}, \mathbf{G}, 0$ uantification of data in $\boldsymbol{E} ; F_{(2,6)}=16.7,{ }^{* *} p=0.0029$, ${ }^{*} p=0.035$ for $\boldsymbol{F} ; F_{(2,6)}=29.7,{ }^{* *} p=0.0021,{ }^{* * *} p=0.0009$ for $\boldsymbol{G} ; \boldsymbol{N}=3$ mice per group, one-way ANOVA.

muscle fiber size (Fig. 11A-C) and muscle force (Fig. 11D-F) in $24 \mathrm{M}$ mice treated with AAV9-SG $\alpha$-GFP compared with AAV9GFP control. Altogether, these observations demonstrate that NMJ deficits and muscle atrophy in aged mice can be mitigated by storing SG $\alpha$ levels, which increases LRP4 by reducing its degradation.

\section{Discussion}

In this paper, we report that LRP4 protein level was reduced in aged muscles. This reduction was associated with diminished tyrosine phosphorylation of MuSK, suggesting compromised agrin-LRP4-MuSK signaling as a potential mechanism of NMJ decline in aged mice. To test this hypothesis, we generated a transgenic mouse strain to express Lrp4 specifically in skeletal muscles and found that conditional overexpression of $\operatorname{Lrp} 4$ in muscles alleviated NMJ fragmentation and denervation and improved NMJ transmission in aged mice. Because $\operatorname{Lrp} 4$ mRNA was not reduced in aged muscles, we posited a compromised stability of LRP4 protein; indeed, ubiquitinated LRP4 was increased in aged mice. Mechanistically, we found that LRP4 interacted with SG $\alpha$, which was critical for LRP4 stability in coexpressing cells and was reduced at aged muscles. Finally, we demonstrate that NMJ decline in aged mice could be ameliorated by AAV9mediated overexpression of SG $\alpha$. These observations demonstrate that agrin-LRP4-MuSK signaling is necessary for NMJ maintenance in aged mice and identify a novel mechanism to regulate LRP4 stability by SG $\alpha$. Our results provide insight into pathological mechanisms of sarcopenia and related NMJ decline and suggest that improved LRP4 stability may be a target for potential therapeutic intervention.

Mechanisms of NMJ decline in aged mice could be complex. Although the AChR delta subunit was increased in aged muscles, there was no change in other subunits (Fig. 1C,D). This is in general agreement with changes at mRNA level: increased for $\alpha$ and delta subunits (Ibebunjo et al., 2013). The increase in $\alpha$ subunit mRNA without parallel increase at protein level suggests a different mechanism for $\alpha$ subunit stability in aged mice. Apparently, changes in AChR mRNAs and proteins in aged muscles are different to those in response to denervation. Both mRNA and protein levels of all subunits are increased in denervated muscles (Wu et al., 2010a; Tintignac et al., 2015; Li et al., 2018). Nevertheless, these results suggest that NMJ decline in aged muscles may not be caused by a reduction in AChR protein levels. Recent evidence indicates that the agrin-LRP4-MuSK signaling is not only important for NMJ formation, but also critical for its maintenance. When agrin, LRP4, or MuSK is ablated in adulthood (i.e., after NMJ formation), NMJ structures are disrupted in mutant mice and neuromuscular transmission compromised (Hesser et al., 2006; Samuel et al., 2012; Barik et al., 2014). Likewise, 
A

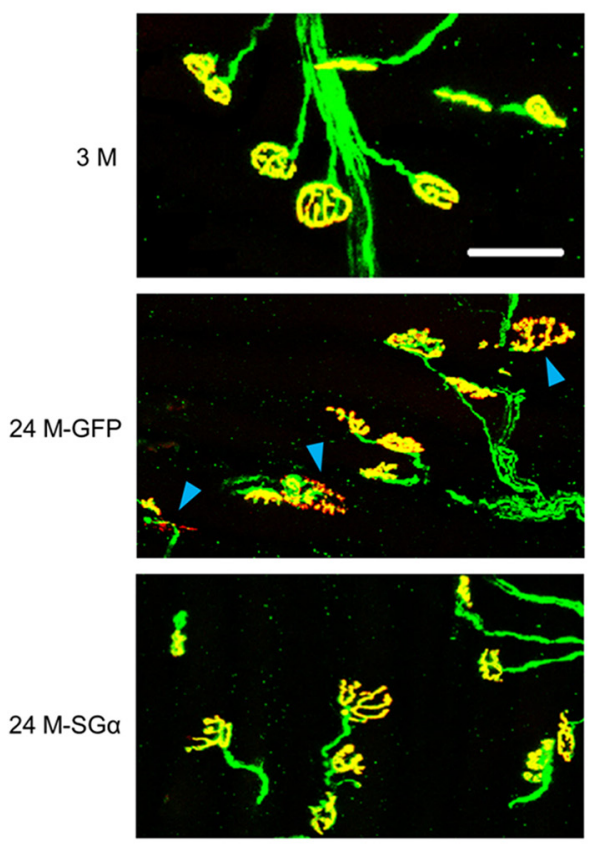

B
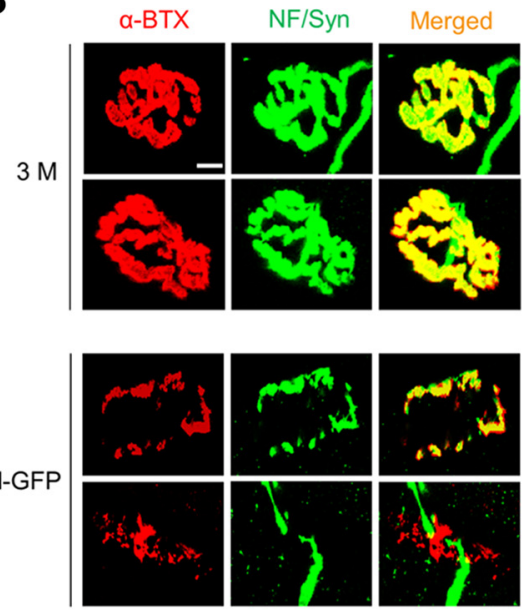

$24 \mathrm{M}-\mathrm{SG} \alpha$

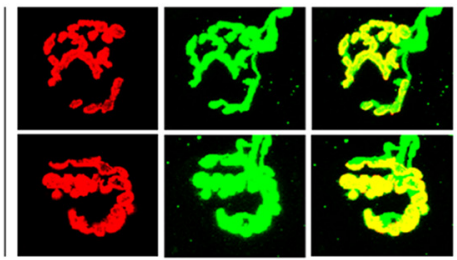

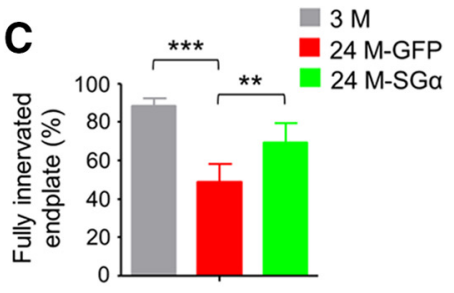

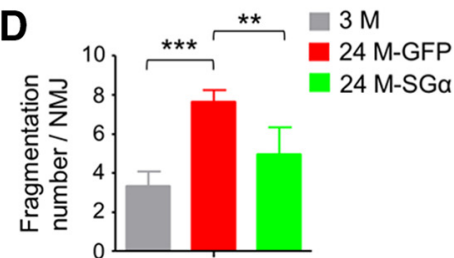

E
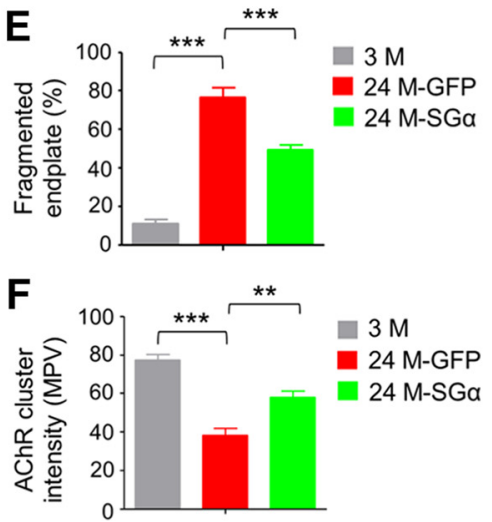

Figure 9. Ameliorated NMJ fragmentation and denervation in aged mice by $S G \alpha$ overexpression. $A$, Reduced fragmentation and improved innervation. Shown were TA muscles of mice at different ages and indicated AAV treatment, whole-mount stained with (F568 $\alpha$-BTX (red) and anti-NF/Syn antibodies (visualized by AlexaFluor 488 goat anti-rabbit lgG; green). Blue arrowhead, denervated or partially innervated endplate. Scale bar, $50 \mu \mathrm{m} . \boldsymbol{B}$, Enlarged images of individual endplates. Scale bar, $10 \mu \mathrm{m}$. $\boldsymbol{C}-\boldsymbol{F}$, Quantitative analysis of data in $\boldsymbol{A}$. $\boldsymbol{C}$, Rescue of denervation in aged mice by $S G \alpha$ expression; $F_{(2,12)}=29,{ }^{* * *} p=0.0001,{ }^{* *} p=0.0051 . \boldsymbol{D}$, Rescue of fragmentation number in aged mice by $S G \alpha$ expression; $F_{(2,12)}=25.8$, ${ }^{* * *} p=0.0001$, ${ }^{* *} p=0.0023$. $E$, Rescue of fragmented endplate percentage in aged mice by $S G \alpha$ expression; $F_{(2,12)}=93,{ }^{* * *} p=0.0001$, ${ }^{* *} p=0.0003$. F, Rescue of reduced AChR cluster intensity in aged mice by $S G \alpha$ expression; $F_{(2,12)}=35.9,{ }^{* * *} p=0.0001,{ }^{* *} p=0.0028 ; N=5$ mice per group, one-way ANOVA.

eliciting antibodies against agrin, LRP4 and MuSK in mice impairs NMJ structure and function (Jha et al., 2006; Klooster et al., 2012; Pevzner et al., 2012; Zhang et al., 2012, 2014; Huijbers et al., 2013; Shen et al., 2013; Yan et al., 2018). Intriguingly, despite increased at mRNA levels in aged mice (Ibebunjo et al., 2013), LRP4 was reduced at protein level. This was associated with reduced tyrosine phosphorylation of MuSK (Fig. 1E-G). Because there was no reduction in AChR subunit proteins in aged muscles, a parsimonious explanation of these results is that NMJ deficits in aged muscles is caused by AChR clustering, possibly because of reduced agrin signaling. This notion is supported by the finding that NMJ deficits in aged mice could be mitigated by restoring LRP4 (Fig. 3).

The pathological significance of NMJ fragmentation is unclear. Although NMJs were "fragmented" in aged mice, the total area labeled by BTX was not reduced (Willadt et al., 2016). We found a reduction in AChR density in NMJ areas of aged muscles and in mEPP amplitudes (Figs. 3F, 4F, 9F, 10F), suggesting impaired neuromuscular transmission. Restoring LRP4 levels diminished these deficits in aged mice, revealing possible mechanisms of improved CMAPs. At the moment, our data were unable to conclude or exclude a role of reduced number of NMJ fragmentations in functional recovery.

It is worthy pointing out that CMAPs are influenced by many biological factors ranging from anatomical and physiological aspects to architectural properties of the muscle, as summarized by a recent review (Rodriguez-Falces and Place, 2018). In particular, CMAP reduction may be caused by increase in axonal recruitment threshold and impaired fiber sarcolemma membrane excitability, in addition to failure in neuromuscular transmission. High-frequency stimulations could deplete readily releasable vesicles. In addition, it could also disrupt the axon firing synchrony and elevate nerve threshold in response to stimuli probably because of axon hyperpolarization (Krnjevic and Miledi, 1958; Duchateau and Hainaut, 1985; Vagg et al., 1998; Rodriguez-Falces and Place, 2018). On postsynaptic side, high-frequency stimulation could increase muscle fiber threshold (Krnjevic and Miledi, 1958; Rodriguez-Falces and Place, 2018). Because restoring LRP4 diminished CMAP deficits in aged mice, future experiments are warranted to determine whether nerve threshold and/or sarcolemma membrane excitability are impaired by aging and their deficits ameliorated by enhancing agrin signaling.

The DGC is a transmembrane complex consisting of (1) cytoskeleton linker proteins dystrophin or utrophin at the synapse, (2) transmembrane proteins dystroglycans $(\alpha, \beta)$, SGs $(\alpha, \beta, \gamma, \delta$ in muscles; $\varepsilon$ and $\zeta$ in other tissues) and sarcospan and (3) cytoplasmic proteins dystrobrevins and syntrophins (Singhal and Martin, 2011; Tintignac et al., 2015; Li et al., 2018). It links the interior cytoskeleton to the ECM and is essential for sarcolemma integrity and thus preventing muscle fiber damage caused by contraction (Ervasti et al., 1990; Sunada and Campbell, 1995; Hack et al., 2000a,b). DGC proteins are present at the NMJ 
A
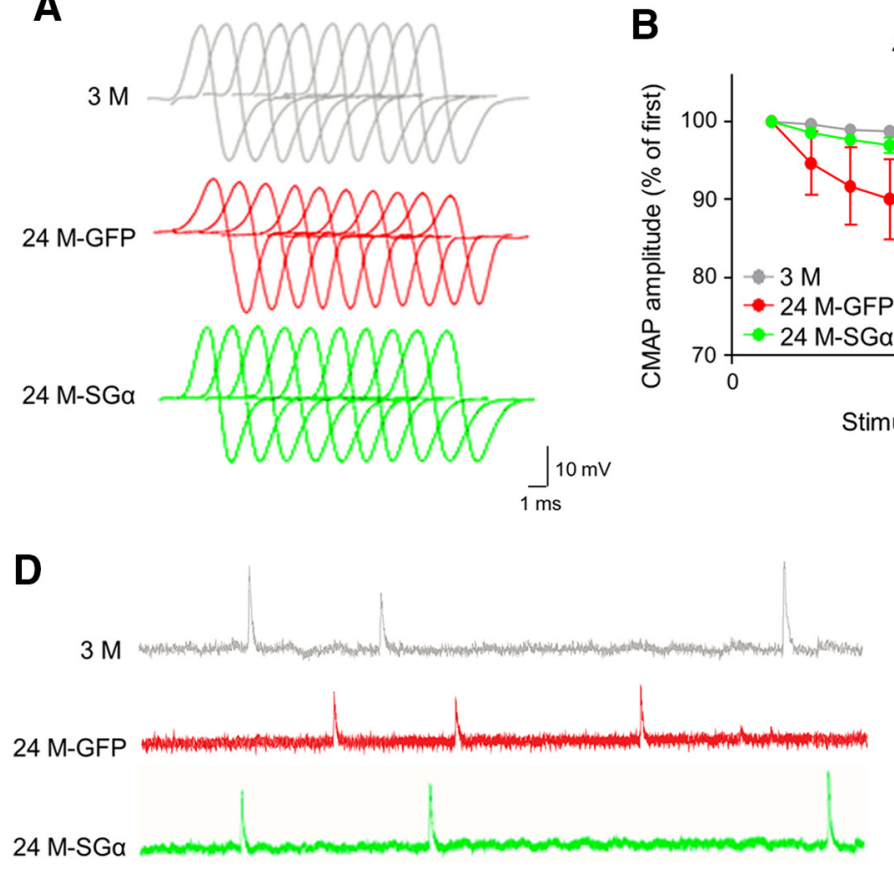

B

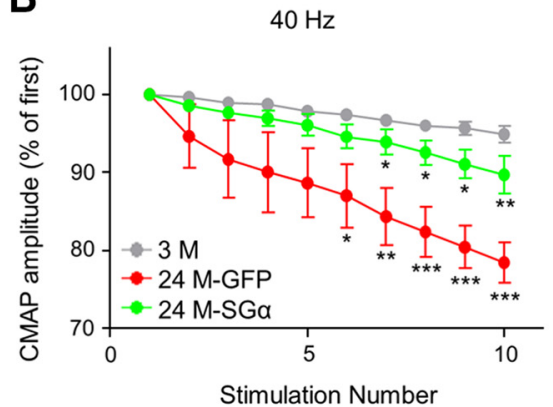

Stimulation Number
C

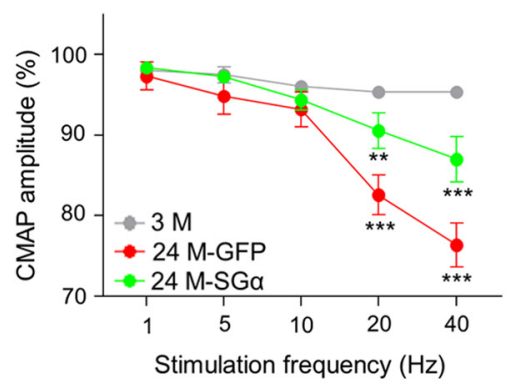

E $\quad 3 \mathrm{M}$

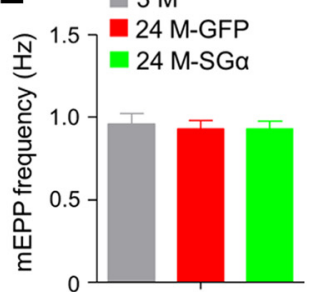

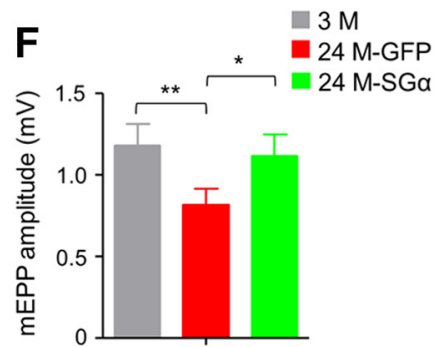

$0.5 \mathrm{mV}$

Figure 10. Improved neuromuscular transmission in aged mice by $S G \alpha$ expression. $\boldsymbol{A}, \boldsymbol{B}$, Reduced ratio of 2nd-10th CMAP amplitudes over the first CMAP amplitude at $40 \mathrm{~Hz}$ stimulations. $\boldsymbol{A}$, Representative traces; $\mathbf{B}$, quantitative data; $F_{(2,90)}=47.7,{ }^{*} p<0.05,{ }^{* *} p<0.01,{ }^{* * *} p<0.001 ; N=4$ mice per group, two-way ANOVA. C, Frequency-dependent CMAP reduction. Shown were ratios of 10 th over first CMAP amplitudes; $F_{(2,45)}=25.2,{ }^{* *} p<0.01,{ }^{* *} p<0.001 ; N=4$ mice per group, two-way ANOVA. $\boldsymbol{D}-\boldsymbol{F}$, Increased mEPP amplitudes of aged mice by AAV-mediated SG $\alpha$ expression. $\boldsymbol{D}$, Representative mEPP traces. $\boldsymbol{E}$, Comparable mEPP frequencies. $\boldsymbol{F}$, Increased mEPP amplitudes in $24 \mathrm{M}-\mathrm{SG} \alpha$ mice compared with $24 \mathrm{M}$-GFP mice; $F_{(2,9)}=13.3,{ }^{* *} p=0.0021$, ${ }^{*} p=0.012$.

A
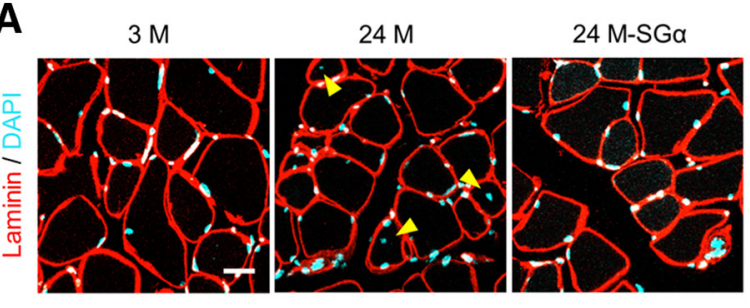

$\mathbf{D}$

$3 \mathrm{M}$

$24 \mathrm{M}$

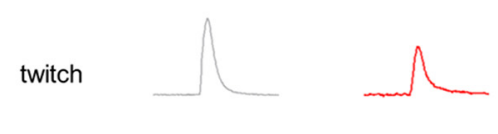

twitch

$50 \mathrm{~Hz}$

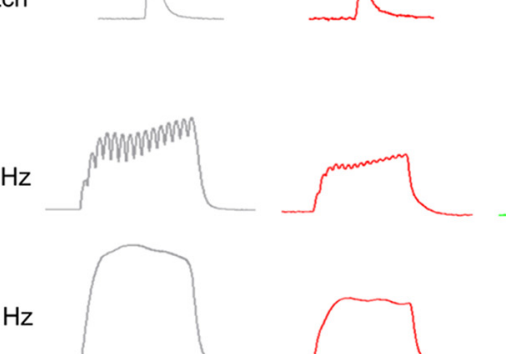

$150 \mathrm{~Hz}$

24 M-SGa
B
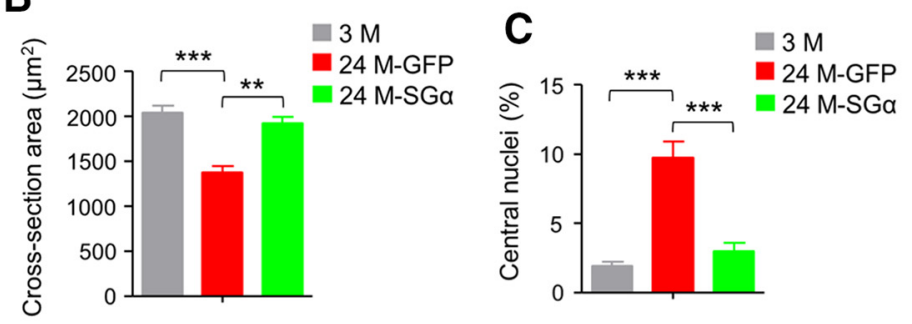
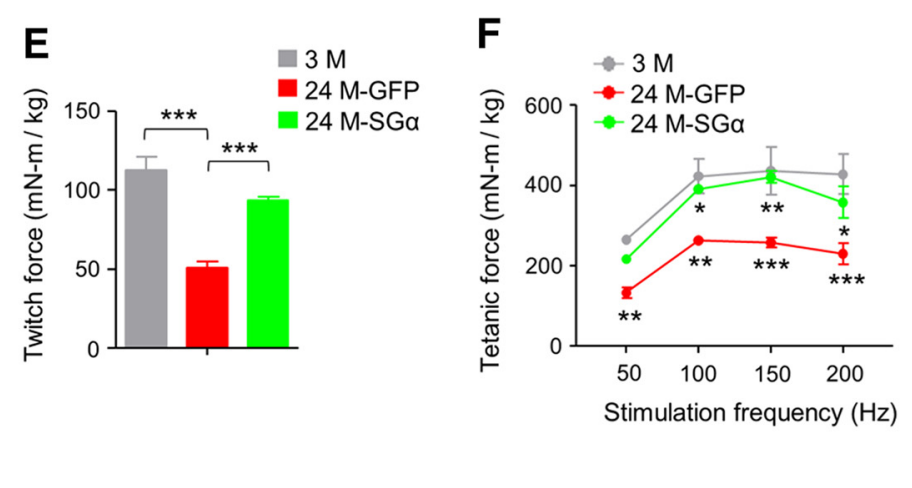

Figure 11. Restored muscle size and strength in aged mice by $S G \alpha$ expression. $A$, Increased cross-section area and reduced central nuclei in aged muscle by $S G \alpha$ expression. Cross-sections of TA muscle were stained with laminin antibody (red) and DAPI (blue). Yellow arrowhead, central nuclei. Scale bar, $20 \mu \mathrm{m}$. $\boldsymbol{B}$, Increased cross-section area in aged mice by $S G \alpha$ expression; $F_{(2,9)}=24.1$, ${ }^{* * *} p=0.0003,{ }^{* *} p=0.0012$. C, Reduced central nuclei in aged mice by $S G \alpha$ expression; $F_{(2,9)}=27.8,{ }^{* * *} p=0.0002,{ }^{* * *} p=0.0006 ; N=4$ mice per group, one-way ANOVA. $D$, Representative twitch (top) and tetanic force at 50 and $150 \mathrm{~Hz}$ (bottom) by sciatic nerve stimulation. $\boldsymbol{E}$, Rescue of reduced twitch force in aged mice by $S G \alpha$ expression; $F_{(2,9)}=35.1,{ }^{* * *} p=0.0001$ and 0.0008 . $\boldsymbol{F}$, Rescue of reduced tetanic force in aged mice by $S G \alpha$ expression; $F_{(2,36)}=34,{ }^{*} p<0.05,{ }^{* *} p<0.01,{ }^{* * *} p<0.001$; N $=4$ mice per group, two-way ANOVA. 
(Ohlendieck et al., 1991b; Adams et al., 2000; Grady et al., 2000). $\alpha$-Dystroglycan could be agrin receptor and perhaps thus contributes to its stabilization in basal lamina (Bowe et al., 1994; Gee et al., 1994; Hara et al., 2011; Tintignac et al., 2015). Mutations in DGC components cause muscular dystrophies; SG $\alpha$ mutations have been identified in various muscular dystrophies including the limb-girdle type 2D (Carrié et al., 1997; Fanin et al., 1997; Murphy and Straub, 2015). NMJ function or morphology in patients with $\mathrm{SG} \alpha$ mutations have not been characterized; however, SG proteins are reduced in patients with dystrophin mutations (Mizuno et al., 1994a,b). In these patients, NMJs are fragmented with reduced density and discontinuous nerve terminal (Theroux et al., 2008; Pratt et al., 2018). In agreement, similar NMJ deficits are displayed in mice lacking dystrophin, $\alpha$-dystrobrevin or $\alpha$-syntrophin (Torres and Duchen, 1987; Lyons and Slater, 1991; Tinsley et al., 1996; Deconinck et al., 1997; Grady et al., 2003).

mRNA levels of Lrp4 and Musk were increased in muscles of aged mice (Ibebunjo et al., 2013; Fig. 6), perhaps as a compensatory mechanism. This however is not sufficient to maintain the normal level of LRP4 (Fig. 1), suggesting an imbalance between LRP4 synthesis and degradation. Our studies show that LRP4 in muscle cells is degraded mainly via proteasome pathways (Fig. $6 B-E$ ). In aged mice, ubiquitinated LRP4 was increased (Fig. $6 D, E)$, suggesting increased degradation at protein level. SG $\alpha$ have been implicated in the stability of multiple proteins and protein complexes such as nNOS, SG $\beta, \mathrm{SG} \gamma, \mathrm{SG} \delta$, and sarcospan. For example, loss of $\mathrm{SG} \alpha$ reduces nNOS stability presumably by causing its dissociation from the plasma membrane (Crosbie et al., 2002). Without $\mathrm{SG} \alpha$, the formation of the sarcoglycan complex and its colocalization with sarcospan and dystroglycans became problematic, leading to loss of these proteins in sarcolemma (Duclos et al., 1998; Crosbie et al., 1999; Gastaldello et al., 2008). The mechanisms by which SG $\alpha$ regulates the stability of LRP4 remain unclear. LRP4 is a transmembrane protein, and thus its membrane association does not require $\mathrm{SG} \alpha$. Interestingly, the level of MuSK, another transmembrane protein that interacts with LRP4 in the presence of agrin, is not reduced in aged muscles, suggesting that the $S G \alpha$ regulation may be specific. Together our results support a model where LRP4 stability requires $\mathrm{SG} \alpha$ in aged muscles and provide insight into molecular mechanism of NMJ decline in aged mice. In support of this model are observations (1) that $\mathrm{SG} \alpha$ and LRP4 interact in muscles (Fig. 7B), (2) that $\mathrm{SG} \alpha$ is reduced at both mRNA and protein levels in aged muscles (Fig. $7 C, D$ ), and (3) that increasing $\mathrm{SG} \alpha$ levels promotes LRP4 stability (Fig. $8 E-G$ ) and viral expression of $S G \alpha$ diminished NMJ deficits in aged mice (Figs. 9, 10). We speculate that $\mathrm{SG} \alpha$ promotes LRP4 stability by linking it to actin cytoskeleton via $\alpha$-dystrobrevin and dystrophin (Campbell and Kahl, 1989; Ohlendieck et al., 1991a,b; Corrado et al., 1994; Yoshida et al., 1994; Grady et al., 1999).

\section{References}

Adams ME, Kramarcy N, Krall SP, Rossi SG, Rotundo RL, Sealock R, Froehner SC (2000) Absence of alpha-syntrophin leads to structurally aberrant neuromuscular synapses deficient in utrophin. J Cell Biol 150: 1385-1398. CrossRef Medline

Arpke RW, Darabi R, Mader TL, Zhang Y, Toyama A, Lonetree CL, Nash N, Lowe DA, Perlingeiro RC, Kyba M (2013) A new immuno-, dystrophindeficient model, the NSG-mdx $(4 \mathrm{Cv})$ mouse, provides evidence for functional improvement following allogeneic satellite cell transplantation. Stem Cells 31:1611-1620. CrossRef Medline

Balice-Gordon RJ (1997) Age-related changes in neuromuscular innervation. Muscle Nerve 5:S83-87. Medline
Banker BQ, Kelly SS, Robbins N (1983) Neuromuscular transmission and correlative morphology in young and old mice. J Physiol 339:355-377. CrossRef Medline

Barik A, Lu Y, Sathyamurthy A, Bowman A, Shen C, Li L, Xiong WC, Mei L (2014) LRP4 is critical for neuromuscular junction maintenance. J Neurosci 34:13892-13905. CrossRef Medline

Bowe MA, Deyst KA, Leszyk JD, Fallon JR (1994) Identification and purification of an agrin receptor from torpedo postsynaptic membranes: a heteromeric complex related to the dystroglycans. Neuron 12:1173-1180. CrossRef Medline

Brennan KJ, Hardeman EC (1993) Quantitative analysis of the human alpha-skeletal actin gene in transgenic mice. J Biol Chem 268:719-725. Medline

Campbell KP, Kahl SD (1989) Association of dystrophin and an integral membrane glycoprotein. Nature 338:259-262. CrossRef Medline

Carrié A, Piccolo F, Leturcq F, de Toma C, Azibi K, Beldjord C, Vallat JM, Merlini L, Voit T, Sewry C, Urtizberea JA, Romero N, Tomé FM, Fardeau M, Sunada Y, Campbell KP, Kaplan JC, Jeanpierre M (1997) Mutational diversity and hot spots in the alpha-sarcoglycan gene in autosomal recessive muscular dystrophy (LGMD2D). J Med Genet 34:470-475. CrossRef Medline

Chai RJ, Vukovic J, Dunlop S, Grounds MD, Shavlakadze T (2011) Striking denervation of neuromuscular junctions without lumbar motoneuron loss in geriatric mouse muscle. PloS One 6:e28090. CrossRef Medline

Corrado K, Mills PL, Chamberlain JS (1994) Deletion analysis of the dystrophin-actin binding domain. FEBS Lett 344:255-260. CrossRef Medline

Courtney J, Steinbach JH (1981) Age changes in neuromuscular junction morphology and acetylcholine receptor distribution on rat skeletal muscle fibres. J Physiol 320:435-447. CrossRef Medline

Crosbie RH, Lebakken CS, Holt KH, Venzke DP, Straub V, Lee JC, Grady RM, Chamberlain JS, Sanes JR, Campbell KP (1999) Membrane targeting and stabilization of sarcospan is mediated by the sarcoglycan subcomplex. J Cell Biol 145:153-165. CrossRef Medline

Crosbie RH, Barresi R, Campbell KP (2002) Loss of sarcolemma nNOS in sarcoglycan-deficient muscle. FASEB J 16:1786-1791. CrossRef Medline

DeChiara TM, Bowen DC, Valenzuela DM, Simmons MV, Poueymirou WT, Thomas S, Kinetz E, Compton DL, Rojas E, Park JS, Smith C, DiStefano PS, Glass DJ, Burden SJ, Yancopoulos GD (1996) The receptor tyrosine kinase MuSK is required for neuromuscular junction formation in vivo. Cell 85:501-512. CrossRef Medline

Deconinck AE, Rafael JA, Skinner JA, Brown SC, Potter AC, Metzinger L, Watt DJ, Dickson JG, Tinsley JM, Davies KE (1997) Utrophindystrophin-deficient mice as a model for Duchenne muscular dystrophy. Cell 90:717-727. CrossRef Medline

Delbono O (2003) Neural control of aging skeletal muscle. Aging Cell 2:2129. CrossRef Medline

Deschenes MR, Roby MA, Eason MK, Harris MB (2010) Remodeling of the neuromuscular junction precedes sarcopenia related alterations in myofibers. Exp Gerontol 45:389-393. CrossRef Medline

Doherty TJ, Vandervoort AA, Brown WF (1993) Effects of ageing on the motor unit: a brief review. Can J Appl Physiol 18:331-358. CrossRef Medline

Duchateau J, Hainaut K (1985) Electrical and mechanical failures during sustained and intermittent contractions in humans. J Appl Physiol 58: 942-947. CrossRef Medline

Duclos F, Straub V, Moore SA, Venzke DP, Hrstka RF, Crosbie RH, Durbeej M, Lebakken CS, Ettinger AJ, van der Meulen J, Holt KH, Lim LE, Sanes JR, Davidson BL, Faulkner JA, Williamson R, Campbell KP (1998) Progressive muscular dystrophy in alpha-sarcoglycan-deficient mice. J Cell Biol 142:1461-1471. CrossRef Medline

Ervasti JM, Ohlendieck K, Kahl SD, Gaver MG, Campbell KP (1990) Deficiency of a glycoprotein component of the dystrophin complex in dystrophic muscle. Nature 345:315-319. CrossRef Medline

Fanin M, Duggan DJ, Mostacciuolo ML, Martinello F, Freda MP, Sorarù G, Trevisan CP, Hoffman EP, Angelini C (1997) Genetic epidemiology of muscular dystrophies resulting from sarcoglycan gene mutations. J Med Genet 34:973-977. CrossRef Medline

Gasperi C, Melms A, Schoser B, Zhang Y, Meltoranta J, Risson V, Schaeffer L, Schalke B, Kröger S (2014) Anti-agrin autoantibodies in myasthenia gravis. Neurology 82:1976-1983. CrossRef Medline

Gastaldello S, D’Angelo S, Franzoso S, Fanin M, Angelini C, Betto R, Sandonà 
D (2008) Inhibition of proteasome activity promotes the correct localization of disease-causing alpha-sarcoglycan mutants in HEK-293 cells constitutively expressing $\beta$-, $\gamma$-, and $\delta$-sarcoglycan. Am J Pathol 173:170181. CrossRef Medline

Gautam M, Noakes PG, Moscoso L, Rupp F, Scheller RH, Merlie JP, Sanes JR (1996) Defective neuromuscular synaptogenesis in agrin-deficient mutant mice. Cell 85:525-535. CrossRef Medline

Gee SH, Montanaro F, Lindenbaum MH, Carbonetto S (1994) Dystroglycanalpha, a dystrophin-associated glycoprotein, is a functional agrin receptor. Cell 77:675-686. CrossRef Medline

Glass DJ, Bowen DC, Stitt TN, Radziejewski C, Bruno J, Ryan TE, Gies DR, Shah S, Mattsson K, Burden SJ, DiStefano PS, Valenzuela DM, DeChiara TM, Yancopoulos GD (1996) Agrin acts via a MuSK receptor complex. Cell 85:513-523. CrossRef Medline

Grady RM, Grange RW, Lau KS, Maimone MM, Nichol MC, Stull JT, Sanes JR (1999) Role for alpha-dystrobrevin in the pathogenesis of dystrophindependent muscular dystrophies. Nat Cell Biol 1:215-220. CrossRef Medline

Grady RM, Zhou H, Cunningham JM, Henry MD, Campbell KP, Sanes JR (2000) Maturation and maintenance of the neuromuscular synapse: genetic evidence for roles of the dystrophin-glycoprotein complex. Neuron 25:279-293. CrossRef Medline

Grady RM, Akaaboune M, Cohen AL, Maimone MM, Lichtman JW, Sanes JR (2003) Tyrosine-phosphorylated and nonphosphorylated isoforms of alpha-dystrobrevin: roles in skeletal muscle and its neuromuscular and myotendinous junctions. J Cell Biol 160:741-752. CrossRef Medline

Grimby G, Saltin B (1983) The ageing muscle. Clin Physiol 3:209-218. CrossRef Medline

Gutmann E, Hanzlíková V (1966) Motor unit in old age. Nature 209:921922. CrossRef Medline

Gutmann E, Hanzlíková V, Vysokocil F (1971) Age changes in cross striated muscle of the rat. J Physiol 216:331-343. CrossRef Medline

Hack AA, Groh ME, McNally EM (2000a) Sarcoglycans in muscular dystrophy. Microsc Res Tech 48:167-180. CrossRef Medline

Hack AA, Lam MY, Cordier L, Shoturma DI, Ly CT, Hadhazy MA, Hadhazy MR, Sweeney HL, McNally EM (2000b) Differential requirement for individual sarcoglycans and dystrophin in the assembly and function of the dystrophin-glycoprotein complex. J Cell Sci 113:2535-2544. Medline

Hamburger V (1980) Trophic interactions in neurogenesis: a personal historical account. Annu Rev Neurosci 3:269-278. CrossRef Medline

Hara Y, Balci-Hayta B, Yoshida-Moriguchi T, Kanagawa M, Beltrán-Valero de Bernabe D, Gündeşli H, Willer T, Satz JS, Crawford RW, Burden SJ, Kunz S, Oldstone MB, Accardi A, Talim B, Muntoni F, Topaloğlu H, Dinçer P, Campbell KP (2011) A dystroglycan mutation associated with limb-girdle muscular dystrophy. New Engl J Med 364:939-946. CrossRef Medline

Hashizume K, Kanda K, Burke RE (1988) Medial gastrocnemius motor nucleus in the rat: age-related changes in the number and size of motoneurons. J Comp Neurol 269:425-430. CrossRef Medline

Hesser BA, Henschel O, Witzemann V (2006) Synapse disassembly and formation of new synapses in postnatal muscle upon conditional inactivation of MuSK. Mol Cell Neurosci 31:470-480. CrossRef Medline

Hoch W, McConville J, Helms S, Newsom-Davis J, Melms A, Vincent A (2001) Auto-antibodies to the receptor tyrosine kinase MuSK in patients with myasthenia gravis without acetylcholine receptor antibodies. Nat Med 7:365-368. CrossRef Medline

Huijbers MG, Zhang W, Klooster R, Niks EH, Friese MB, Straasheijm KR, Thijssen PE, Vrolijk H, Plomp JJ, Vogels P, Losen M, Van der Maarel SM, Burden SJ, Verschuuren JJ (2013) MuSK IgG4 autoantibodies cause myasthenia gravis by inhibiting binding between MuSK and Lrp4. Proc Natl Acad Sci U S A 110:20783-20788. CrossRef Medline

Ibebunjo C, Chick JM, Kendall T, Eash JK, Li C, Zhang Y, Vickers C, Wu Z, Clarke BA, Shi J, Cruz J, Fournier B, Brachat S, Gutzwiller S, Ma Q, Markovits J, Broome M, Steinkrauss M, Skuba E, Galarneau JR, et al. (2013) Genomic and proteomic profiling reveals reduced mitochondrial function and disruption of the neuromuscular junction driving rat sarcopenia. Mol Cell Biol 33:194-212. CrossRef Medline

Ingalls CP, Warren GL, Zhang JZ, Hamilton SL, Armstrong RB (2004) Dihydropyridine and ryanodine receptor binding after eccentric contractions in mouse skeletal muscle. J Appl Physiol 96:1619-1625. CrossRef Medline

Jha S, Xu K, Maruta T, Oshima M, Mosier DR, Atassi MZ, Hoch W (2006)
Myasthenia gravis induced in mice by immunization with the recombinant extracellular domain of rat muscle-specific kinase (MuSK). J Neuroimmunol 175:107-117. CrossRef Medline

Kawabuchi M, Zhou CJ, Wang S, Nakamura K, Liu WT, Hirata K (2001) The spatiotemporal relationship among Schwann cells, axons and postsynaptic acetylcholine receptor regions during muscle reinnervation in aged rats. Anat Rec 264:183-202. CrossRef Medline

Kelly SS, Robbins N (1983) Progression of age changes in synaptic transmission at mouse neuromuscular junctions. J Physiol 343:375-383. CrossRef Medline

Kim N, Stiegler AL, Cameron TO, Hallock PT, Gomez AM, Huang JH, Hubbard SR, Dustin ML, Burden SJ (2008) Lrp4 is a receptor for agrin and forms a complex with MuSK. Cell 135:334-342. CrossRef Medline

Klooster R, Plomp JJ, Huijbers MG, Niks EH, Straasheijm KR, Detmers FJ, Hermans PW, Sleijpen K, Verrips A, Losen M, Martinez-Martinez P, De Baets MH, van der Maarel SM, Verschuuren JJ (2012) Muscle-specific kinase myasthenia gravis IgG4 autoantibodies cause severe neuromuscular junction dysfunction in mice. Brain 135:1081-1101. CrossRef Medline Krnjevic K, Miledi R (1958) Failure of neuromuscular propagation in rats. J Physiol 140:440-461. CrossRef Medline

Kurokawa K, Mimori Y, Tanaka E, Kohriyama T, Nakamura S (1999) Agerelated change in peripheral nerve conduction: compound muscle action potential duration and dispersion. Gerontology 45:168-173. CrossRef Medline

Larsson L, Ansved T (1995) Effects of ageing on the motor unit. Prog Neurobiol 45:397-458. CrossRef Medline

Li L, Cao Y, Wu H, Ye X, Zhu Z, Xing G, Shen C, Barik A, Zhang B, Xie X, Zhi W, Gan L, Su H, Xiong WC, Mei L (2016) Enzymatic activity of the scaffold protein rapsyn for synapse formation. Neuron 92:1007-1019. CrossRef Medline

Li L, Xiong WC, Mei L (2018) Neuromuscular junction formation, aging, and disorders. Annu Rev Physiol 80:159-188. CrossRef Medline

Li XM, Dong XP, Luo SW, Zhang B, Lee DH, Ting AK, Neiswender H, Kim CH, Carpenter-Hyland E, Gao TM, Xiong WC, Mei L (2008) Retrograde regulation of motoneuron differentiation by muscle beta-catenin. Nat Neurosci 11:262-268. CrossRef Medline

Li Y, Lee Y, Thompson WJ (2011) Changes in aging mouse neuromuscular junctions are explained by degeneration and regeneration of muscle fiber segments at the synapse. J Neurosci 31:14910-14919. CrossRef Medline

Luo S, Zhang B, Dong XP, Tao Y, Ting A, Zhou Z, Meixiong J, Luo J, Chiu FC, Xiong WC, Mei L (2008) HSP90 beta regulates rapsyn turnover and subsequent AChR cluster formation and maintenance. Neuron 60:97110. CrossRef Medline

Lyons PR, Slater CR (1991) Structure and function of the neuromuscular junction in young adult mdx mice. J Neurocytol 20:969-981. CrossRef Medline

Macpherson PC, Farshi P, Goldman D (2015) Dach2-Hdac9 signaling regulates reinnervation of muscle endplates. Development 142:4038-4048. CrossRef Medline

Merlie JP, Sanes JR (1985) Concentration of acetylcholine receptor mRNA in synaptic regions of adult muscle fibres. Nature 317:66-68. CrossRef Medline

Messi ML, Delbono O (2003) Target-derived trophic effect on skeletal muscle innervation in senescent mice. J Neurosci 23:1351-1359. CrossRef Medline

Mittal KR, Logmani FH (1987) Age-related reduction in 8th cervical ventral nerve root myelinated fiber diameters and numbers in man. J Gerontol 42:8-10. CrossRef Medline

Mizuno Y, Yoshida M, Nonaka I, Hirai S, Ozawa E (1994a) Expression of utrophin (dystrophin-related protein) and dystrophin-associated glycoproteins in muscles from patients with Duchenne muscular dystrophy. Muscle Nerve 17:206-216. CrossRef Medline

Mizuno Y, Noguchi S, Yamamoto H, Yoshida M, Suzuki A, Hagiwara Y, Hayashi YK, Arahata K, Nonaka I, Hirai S, Ozawa E (1994b) Selective defect of sarcoglycan complex in severe childhood autosomal recessive muscular dystrophy muscle. Biochem Biophys Res Commun 203:979_ 983. CrossRef Medline

Murphy AP, Straub V (2015) The classification, natural history and treatment of the limb girdle muscular dystrophies. J Neuromuscul Dis 2:S7S19. CrossRef Medline

Ohlendieck K, Ervasti JM, Snook JB, Campbell KP (1991a) Dystrophin- 
glycoprotein complex is highly enriched in isolated skeletal muscle sarcolemma. J Cell Biol 112:135-148. CrossRef Medline

Ohlendieck K, Ervasti JM, Matsumura K, Kahl SD, Leveille CJ, Campbell KP (1991b) Dystrophin-related protein is localized to neuromuscular junctions of adult skeletal muscle. Neuron 7:499-508. CrossRef Medline

Pellegrino C, Franzini C (1963) An electron microscope study of denervation atrophy in red and white skeletal muscle fibers. J Cell Biol 17:327349. CrossRef Medline

Pevzner A, Schoser B, Peters K, Cosma NC, Karakatsani A, Schalke B, Melms A, Kröger S (2012) Anti-LRP4 autoantibodies in AChR- and MuSKantibody-negative myasthenia gravis. J Neurol 259:427-435. CrossRef Medline

Pratt SJP, Iyer SR, Shah SB, Lovering RM (2018) Imaging analysis of the neuromuscular junction in dystrophic muscle. Methods Mol Biol 1687: 57-72. CrossRef Medline

Rodriguez-Falces J, Place N (2018) Determinants, analysis and interpretation of the muscle compound action potential (M wave) in humans: implications for the study of muscle fatigue. Eur J Appl Physiol 118:501521. CrossRef Medline

Roos MR, Rice CL, Vandervoort AA (1997) Age-related changes in motor unit function. Muscle Nerve 20:679-690. CrossRef Medline

Rosenheimer JL (1990) Ultraterminal sprouting in innervated and partially denervated adult and aged rat muscle. Neuroscience 38:763-770. CrossRef Medline

Samuel MA, Valdez G, Tapia JC, Lichtman JW, Sanes JR (2012) Agrin and synaptic laminin are required to maintain adult neuromuscular junctions. PloS One 7:e46663. CrossRef Medline

Sanes JR, Lichtman JW (2001) Induction, assembly, maturation and maintenance of a postsynaptic apparatus. Nat Rev Neurosci 2:791-805. CrossRef Medline

Shen C, Lu Y, Zhang B, Figueiredo D, Bean J, Jung J, Wu H, Barik A, Yin DM, Xiong WC, Mei L (2013) Antibodies against low-density lipoprotein receptor-related protein 4 induce myasthenia gravis. J Clin Invest 123: 5190-5202. CrossRef Medline

Singhal N, Martin PT (2011) Role of extracellular matrix proteins and their receptors in the development of the vertebrate neuromuscular junction. Dev Neurobiol 71:982-1005. CrossRef Medline

Stonnington HH, Engel AG (1973) Normal and denervated muscle: a morphometric study of fine structure. Neurology 23:714-724. CrossRef Medline

Sunada Y, Campbell KP (1995) Dystrophin-glycoprotein complex: molecular organization and critical roles in skeletal muscle. Curr Opin Neurol 8:379-384. CrossRef Medline

Theroux MC, Olivant A, Akins RE (2008) Chistomorphology of neuromuscular junction in duchenne muscular dystrophy. Paediatr Anaesth 18: 256-259. CrossRef Medline

Tinsley JM, Potter AC, Phelps SR, Fisher R, Trickett JI, Davies KE (1996) Amelioration of the dystrophic phenotype of $\mathrm{mdx}$ mice using a truncated utrophin transgene. Nature 384:349-353. CrossRef Medline

Tintignac LA, Brenner HR, Rüegg MA (2015) Mechanisms regulating neuromuscular junction development and function and causes of muscle wasting. Physiol Rev 95:809-852. CrossRef Medline

Tomlinson BE, Irving D (1977) The numbers of limb motor neurons in the human lumbosacral cord throughout life. J Neurol Sci 34:213-219. CrossRef Medline

Torres LF, Duchen LW (1987) The mutant mdx: inherited myopathy in the mouse: morphological studies of nerves, muscles and end-plates. Brain 110:269-299. CrossRef Medline

Vagg R, Mogyoros I, Kiernan MC, Burke D (1998) Activity-dependent hyperpolarization of human motor axons produced by natural activity. J Physiol 507:919-925. CrossRef Medline

Valdez G, Tapia JC, Kang H, Clemenson GD Jr, Gage FH, Lichtman JW, Sanes JR (2010) Attenuation of age-related changes in mouse neuromuscular synapses by caloric restriction and exercise. Proc Natl Acad Sci U S A 107:14863-14868. CrossRef Medline

Valdez G, Tapia JC, Lichtman JW, Fox MA, Sanes JR (2012) Shared resistance to aging and ALS in neuromuscular junctions of specific muscles. PloS One 7:e34640. CrossRef Medline

van der Ven PF, Schaart G, Jap PH, Sengers RC, Stadhouders AM, Ramaekers FC (1992) Differentiation of human skeletal muscle cells in culture: maturation as indicated by titin and desmin striation. Cell Tissue Res 270:189-198. CrossRef Medline

Wang Q, Hebert SL, Rich MM, Kraner SD (2011) Loss of synaptic vesicles from neuromuscular junctions in aged MRF4-null mice. Neuroreport 22:185-189. CrossRef Medline

Weatherbee SD, Anderson KV, Niswander LA (2006) LDL-receptor-related protein 4 is crucial for formation of the neuromuscular junction. Development 133:4993-5000. CrossRef Medline

Willadt S, Nash M, Slater CR (2016) Age-related fragmentation of the motor endplate is not associated with impaired neuromuscular transmission in the mouse diaphragm. Sci Rep 6:24849. CrossRef Medline

Wu H, Xiong WC, Mei L (2010a) To build a synapse: signaling pathways in neuromuscular junction assembly. Development 137:1017-1033. CrossRef Medline

Wu H, Lu Y, Shen C, Patel N, Gan L, Xiong WC, Mei L (2012) Distinct roles of muscle and motoneuron LRP4 in neuromuscular junction formation. Neuron 75:94-107. CrossRef Medline

Wu Z, Yang H, Colosi P (2010b) Effect of genome size on AAV vector packaging. Mol Ther 18:80-86. CrossRef Medline

Yan M, Liu Z, Fei E, Chen W, Lai X, Luo B, Chen P, Jing H, Pan JX, Rivner MH, Xiong WC, Mei L (2018) Induction of anti-agrin antibodies causes myasthenia gravis in mice. Neuroscience 373:113-121. CrossRef Medline

Yang S, Chang R, Yang H, Zhao T, Hong Y, Kong HE, Sun X, Qin Z, Jin P, Li S, Li XJ (2017) CRISPR/Cas9-mediated gene editing ameliorates neurotoxicity in mouse model of Huntington's disease. J Clin Invest 127:27192724. CrossRef Medline

Yoshida M, Suzuki A, Yamamoto H, Noguchi S, Mizuno Y, Ozawa E (1994) Dissociation of the complex of dystrophin and its associated proteins into several unique groups by $n$-octyl $\beta$-D-glucoside. Eur J Biochem 222:10551061. CrossRef Medline

Zhang B, Luo S, Wang Q, Suzuki T, Xiong WC, Mei L (2008) LRP4 serves as a coreceptor of agrin. Neuron 60:285-297. CrossRef Medline

Zhang B, Tzartos JS, Belimezi M, Ragheb S, Bealmear B, Lewis RA, Xiong WC, Lisak RP, Tzartos SJ, Mei L (2012) Autoantibodies to lipoproteinrelated protein 4 in patients with double-seronegative myasthenia gravis. Arch Neurol 69:445-451. CrossRef Medline

Zhang B, Shen C, Bealmear B, Ragheb S, Xiong WC, Lewis RA, Lisak RP, Mei L (2014) Autoantibodies to agrin in myasthenia gravis patients. PloS One 9:e91816. CrossRef Medline

Zhao K, Shen C, Lu Y, Huang Z, Li L, Rand CD, Pan J, Sun XD, Tan Z, Wang H, Xing G, Cao Y, Hu G, Zhou J, Xiong WC, Mei L (2017) Muscle yap is a regulator of neuromuscular junction formation and regeneration. J Neurosci 37:3465-3477. CrossRef Medline 